\title{
Inkblots as a cultural phenomenon: On the centenary of the Rorschach test
}

\author{
Plamy atramentowe jako zjawisko kulturowe - w stulecie powstania testu Rorschacha
}

\author{
Anna Hunca-Bednarska ABCDEF, \\ MONAR Center in Lublin \\ In memory of Rev. Prof. Zdzisław Chlewiński, PhD, DSc, \\ my doctoral dissertation supervisor, Mentor, and Friend. $~$ Author \\ Pamięci księdza prof. dra habil. Zdzisława Chlewińskiego, \\ Promotora mojej pracy doktorskiej, mego Mentora i Przyjaciela Autorka
}

\begin{abstract}
Introduction: Approved or not, the Hermann Rorschach test can be considered more than just a test to a clinical trial. Reflection on it as a broader phenomenon may yield what is the most valuable: better knowledge of human nature.

Objective: This article aims to present the dual nature of Rorschach's inkblots: as a test of "guessing" the meaning of signs and as a test of perception.

Method: Narrative literature review on the meaning and interpretation of the Rorschach test.

Results:

The nature and reception of inkblots. The inkblots have a dual nature: they require visual perception, and at the same time they are signs, whose meanings are extracted in the process of interpretation. This process is largely subject to cultural determinants; it also depends on the structure of stimuli and on their artistic expression.

Charles Sanders Peirce's theory of signs and the sign nature of inkblots. According to Peirce, the interpretation of a sign, as a triadic structure, belongs to the ontic order and is a continuous process, taking place perpetually. Mental interpretation, as it were, follows the ontic dimension and constitutes a kind of reflection of this dimension.

The phenomenology of perception and the interpretation of inkblots. Perception as viewed by Rorschach found its unintended, though strikingly consistent, complement in the philosophy of Maurice Merleau-Ponty. This is particularly clear in the acknowledgment of the role of the body in perception and in emphasis placed on the active and dynamic nature of the subjectobject relationship.

Rorschach and Merleau-Ponty vs. Peirce: similarities and differences. The seemingly completely different ways of understanding interpretation in Peirce's semiotics (indirect cognition) and in Merleau-Ponty's phenomenology (direct cognition), actually show important similarities. I draw attention to the ontic dimension of interpretation and its systemic character, which both philosophers stress, and to the view of interpretation as a perpetual process that is never completed, both in Peirce's semiotics and in Merleau-Ponty's phenomenology.

Conclusion. The semiotic and perceptual nature of the inkblots created by the Swiss psychiatrist reflects two basic and mutually complementary ways in which humans experience the world. This experience has both a psychological and an ontic nature, which makes it possible for an examination using the Rorschach test to become an encounter with an existential dimension.
\end{abstract}

Keywords: Rorschach test, cultural determinants, theory of signs, phenomenology of perception

\section{Streszczenie}

Wstęp: Test Hermanna Rorschacha można traktować jako coś więcej niż tylko test, aprobowany czy nie, do badania klinicznego. Refleksja nad nim, jako nad szerszym zjawiskiem, może dać to, co w końcu najcenniejsze: lepsze poznanie natury ludzkiej.

Cel: Celem niniejszego artykułu jest przedstawienie podwójnego charakteru plam Rorschacha: jako testu „odgadywania” znaczenia znaków i jako testu badającego percepcję.

Metoda: Narracyjny przegląd literatury dotyczącej tematu znaczenia i interpretacji testu plam Rorschacha. 


\section{Wyniki:}

Natura plam i ich recepcja. Plamy atramentowe mają podwójny charakter: wymagają percepcji wzrokowej a jednocześnie są znakami, których znaczenia zostają wydobywane $\mathrm{w}$ procesie interpretacji. Proces ten $\mathrm{w}$ dużym stopniu podlega uwarunkowaniom kulturowym, a także jest zależny od ustrukturowania bodźców oraz od ich artystycznego wyrazu.

Teoria znaku Charlesa Sandersa Pearce'a, a znakowy charakter plam atramentowych. Według Peirce'a interpretacja znaku, jako struktury triadycznej należy do porządku ontycznego i jest procesem ciągłym, nieustannie się realizującym. Interpretacja mentalna podąża za wymiarem ontycznym i jest jego pewnym odzwierciedleniem.

Fenomenologia percepcji a interpretacja plam. Percepcja w ujęciu Rorschacha znalazła swe niezamierzone, lecz uderzająco konsekwentne dopełnienie w filozofii Maurice’a Merleau-Ponty'ego. Jest ono szczególnie wyraziste w uwzględnianiu roli ciała w percepcji i podkreślaniu aktywnej, dynamicznej relacji: podmiot-przedmiot.

Rorschach i Merleau-Ponty a Peirce, co łączy ich, a co dzieli. Zupełnie różne, na pozór, rozumienie interpretacji w semiotyce Peirce'a (poznanie o charakterze pośrednim) niż w fenomenologii Merleau-Ponty’ego (poznanie bezpośrednie), w istocie kryje w sobie ważne podobieństwa. Zwracam uwagę na ontyczny wymiar interpretacji i jej systemowy charakter, co podkreślają obaj filozofowie, a także na ujęcie interpretacji jako procesu nieustannego, nigdy nie zakończonego, zarówno w semiotyce Peirce’a jak i w fenomenologii Merleau-Ponty'ego.

Wnioski. Znakowa i percepcyjna natura stworzonych przez szwajcarskiego psychiatrę plam odzwierciedla dwa podstawowe i uzupełniające się wzajemnie sposoby ludzkiego doświadczania świata. Doświadczanie to ma zarówno swój psychologiczny, jak i ontyczny charakter, co sprawia, że badanie testem Rorschacha może stać się spotkaniem o wymiarze egzystencjalnym.

Słowa kluczowe: test Rorschacha, uwarunkowania kulturowe, teoria znaku, fenomenologia percepcji

\section{Introduction}

In September 1921 in Bern, Hermann Rorschach published a monograph entitled Psychodiagnistik, in which he presented ten inkblot cards that he intended for use in the experimental study of perception. Very soon, however, the inkblots created by the Swiss psychiatrist began to be treated as a psychological test sensu stricto. This tendency gained momentum around 1926, when Rorschach's cards became increasingly popular in the United States. These were also years that saw the dynamic development of psychometrics, which resulted in various attempts to make Rorschach's method a test meeting the criteria of measurability and accuracy. This way of treating the cards also became the source of criticism sometimes very severe - against the test as one that failed to give fairly objective knowledge about the examinee. It is hardly possible to deny the legitimacy of many such reservations, but it must be noted that, at the same time, new attempts were made to develop measurable criteria for this test.

At any rate, it cannot be denied that examination using the Rorschach test can be a source of truly valuable information about the examinee, just like other informal methods, such as psychodrawing or conversation, can be highly valuable sources of this kind of information.

In the case of the Rorschach test, a very intriguing fact is that its phenomenon goes beyond the utilitarian value of psychological examination: the test can, and - I believe - should, be considered also as a cultural phenomenon, a compelling subject of research and reflection for everyone interested in the broadly defined humanities. It can preoccupy the thoughts of a researcher investigating signs and one interested in perception issues. As a result, the Rorschach test has become something more than merely a clinical assessment test, approved or not; it is a broader phenomenon, and reflection on it may provide what is, ultimately, the most valuable: better knowledge of human nature.

Personally, I am convinced that this test not only unfolds the layer of the psyche that I call the psychological layer but also moves the deeper strata of a given individual's experience, linked with their experience of the world and their place in it, and that, at the same time, it constitutes valuable material for scholars exploring signs and for perception researchers.

In the present article I intend to discuss the dual character of Rorschach's inkblots: as a test that involves "guessing at" the meaning of signs and as a perception test.

In the first section I focus precisely on the character of the inkblots, showing their dual nature: they are objects of perception and at the same time signs whose designata "demands" identification.

The sign nature of the inkblots has been noted but has not been analyzed in much detail so far. In my opinion, this problem can be very fruitfully considered in the light of Charles Sanders Peirce's theory of signs. The second section of the present article will be devoted to this issue.

In the third section I discuss Rorschach's inkblots as objects of perception, particularly in the light of Maurice Merleau-Ponty's phenomenology of perception. Apart from one mention in the context of Rorschach (in Helen Malmgren), I have found no discussion of these issues in 
the literature.

The fourth section is an attempt at a comprehensive look at the Rorschach test: as both a perception test and a test that involves "guessing at" the meaning of signs.

In the Conclusion section I highlight the significance of the Rorschach test as one that addresses universal human experience associated with the generally defined human condition.

\section{The nature and reception of inkblots}

1. The inkblots created by Rorschach are marked by perfect harmony between what is familiar and what is unknown and between what is organized and what is entirely unconstrained

It can be said that, if psychological projection methods based on the analysis of examinees' products (e.g. psychodrawing) are excluded, the inkblots making up the Rorschach test are the least structured material of all stimuli used in psychological examination. It is, therefore, assumed that everything the examinee has seen in the inkblot, results from pure projection, an outcome of his or her psyche being projected on the inkblot. This attitude can traced back to Rorschach's statement that the inkblots were created by "throwing" paint onto a sheet of paper (a kind of bibulous paper) and then folding the sheet in half. A stimulus thus created would have to be not only symmetrical but also random and arbitrary. It is, however, worth noting the Rorschach's other statements, too. The author of the test asserted, for example, that the inkblots should meet certain conditions of good composition and, more importantly, that they were to resemble many things whose images - engrams - were coded in human minds. In fact, the Swiss psychiatrist made many changes to the inkblots in such a way as to ensure that they met his expectations [1]. Relying on the work of art of historian Dario Gamboni, Naamah Akavia stresses how intensely Rorschach worked on the graphic expression of his cards - for instance, how much effort he made to maintain the appropriate valorization of colors (shading) [2].

It can be said that the inkblots do not present anything specific clearly enough, but still there are images of many things hidden in them that can be extracted. This has been pointed out by Władysław Paluchowski, who writes that "an inkblot is a set of models of real objects" [3]. Further, one must admit that some of these models are easy to discover and that sometimes they suggest themselves directly, as it were, while others are more difficult to see and take greater effort to discern. Those images that are more original and difficult to extract may be less strongly supported by the features of a given inkblot, but it also sometimes happens that they are highly congruous with these features. In every interpretation system the psychologist evaluates the congruity of the examinee's responses, which suggests a certain objectivity of the meaning of inkblots. The inkblots are usually assumed not to have denotative meanings but only connotative and emotional ones [4], since they are not pictures presenting a particular thing. One can speak of denotative meaning when a sign clearly points to a certain object or concept. Connotative meaning is the case when the sign evokes additional associations, particularly ones that are emotionally charged. It should be noted that these additional associations are not directly related to the semantic scope of the concept.

As John Exner writes, the Rorschach test inkblots have certain features (critical distal bits) that support some interpretations and discredit others. The inkblots can be said to be polysemous signs, with a wide range of possible interpretations. They are not amorphous stimuli but ones that have their structure and specific formal features. The structured nature of the inkblots is stressed especially by those psychologists who understand the examinee's activity as mainly cognitive and the examination using the Rorschach test as a kind of decisionmaking situation associated with solving problems. The significance of the organization that can be noticed in the inkblots is underscored by Paluchowski: "the essence of the examinee's actions consists not only in the selection of the emerging associations but also in actively extracting from the inkblot what serves as the basis for verbalization" [3]. This author observes that not everything amounts to projection. After all, examinees' responses are determined not only by their individual characteristics but also by the features of the inkblot; what is a feature of perception itself, characteristic of the examinee, should therefore be distinguished from what is determined by the features of the stimulus. At first glance, the inkblots seem to be arbitrary, but it is possible to discover a hidden structure in them; they seem to be symmetrical, but it is often easier to discern an object in one half of the inkblot than it is in the other; they seem not to represent anything specific, but nevertheless, there are numerous designata hidden in them. The observation arises that the stimuli of the test in question are marked by a balance of contrary characteristics. What the examinee can see in the inkblot is determined by its features, but which features are chosen and in which configuration is not easy to predict. Damion Searls writes: "Rorschach inkblots are like the act of seeing, which itself has both structure and latitude. There's something really there, but not anything that constrains us completely. The visual nature of the world is objectively in things, but we see it there; we subjectively impose our view of the world onto things, but only if that view fits what we see. We're all looking at the same thing, even when we see it differently" [5].

2. Various ways of interpreting the inkblots 
are largely determined by their specific characteristics as stimuli

Interestingly, the formal features of the inkblots have been analyzed by art historians. A psychologist, but above all, an art theorist and philosopher Rudolf Arnheim wrote: "the responses to totally unstructured stimulation are poor and gratuitous. It takes a rich assortment of clearly articulate but ambiguous patterns, such as those of the Rorschach inkblots, to make the mind respond with acts of recognition. Recognition presupposes the presence of something to be recognized" [6]. Arnheim analyzed the meanings coded in the formal features of the inkblots. The results of his analysis concerning the first card of the test are reported by Searls. It turns out, for instance, that different perspectives on the internal organization of the inkblot are possible [5]. My many years of practice in using the Rorschach test confirm that some of such internal structures of inkblots suggest themselves to the examinee, while others are not easy to "extract".

The characteristics of inkblots often provoke contrary feelings and interpretations. The tenth card of the test may serve as an example. This card often gives the impression of excessive diversity and chaos, making it difficult to find an appropriate interpretation. Here is a response of a thirty-year-old man to this card: "Oh my! This is so colorful and very distracting, it is hard to see exactly". A twenty-four-year-old female student, by contrast, perceived the tenth card as very well organized space. This is her response: "A garden, beautiful lawns, flower beds located on both sides symmetrically, trim and colorful; this makes a fine impression" [7]. What is important and intriguing, is the fact that the structure of the inkblot provides support both for the impression of chaos and for the sense of order. Even the perception of movement, which is often treated as a manifestation of pure projection [8], may be determined by "ordinary" features of the inkblot. As Arnheim points out, a slanting position or wedge-shaped form of elements is enough for dynamism to emanate from an image [9]. It also happens that the shape of inkblots suggests contradictory contents. An example can be the third card, in which human figures are often discerned, but the shape of their heads may also evoke an image of bird or animal heads or animals with elongated muzzles. Examinees do not usually notice these additional possibilities, but sometimes there are responses such as: "These could be people if the shape of their heads did not resemble birds". Sometimes examinees combine these two images ("These are people with beaks, sort of"), but they remain critical of their interpretation. It also happens that two different images merge closely together, resulting in a contaminated image confirmed by appropriate verbalization ("These are birdmen"). Contamination is often considered to be a symptom of cognitive disorders, whereas in my opinion the acceptance of the polysemous nature of inkblots and proper distance from the contradictions present in them are linked with psychological maturity.

3. The pictorial culture of the Western world is not conducive to the understanding that visual perception is a complex phenomenon

Tom Mitchell points out that seeing seems to be something straightforward and natural, but he immediately adds that this statement refers only to the simplest visual abilities [10]. It should be noted, however, that the sense of the obviousness of visual perception is characteristic mainly of the culture of the Western world, and the experiments conducted by Jan Deręgowski of the University of Aberdeen suggest that even very basic visual abilities can pose a problem, especially in cultures unfamiliar with images as products of culture. This professor's research showed that, when presented with drawings of familiar objects or with photographs of their family members, subjects from non-Western societies often felt intense anxiety, felt confused, were unable to distinguish the drawing from the ground it was made on, and were unable to indicate what the figure was and what the ground in the picture was [11]. The already mentioned Arnheim regards the ability to distinguish figure and ground as fundamental and more basic than form perception. It also proved to be a difficulty for members of "pre-pictorial" cultures to make a synthesis of image elements and integrate them into a whole.

Some ways of reacting found in Rorschach test examinees belonging to the Western culture can be observed to be similar to the reactions of people from cultures unfamiliar with images. It can be said that what takes place in their case is regression in the reception of images, but the regression is provoked by the polysemous character of the stimuli. One of the examples of this way of reacting may be the phenomenon called "inductive perception" [8]. Inductive perception is the case when the person, who is looking at an inkblot, fails to see an object in its entirety at first but focuses on its elements, names them, and gradually, with some delay, links them with one another in order to realize at the end of this process that they have made up a certain whole that they are now able to identify and name. For example, an examinee says: "Oh, the feet are here, the legs are here, the arms are here, and the head, too - this is some kind of figure".

Deręgowski observed that some members of nonpictorial cultures adopt one of two opposing attitudes: they either take images for real objects, or on the contrary, find themselves unable to attribute any meaning to images whatsoever [11]. I am inclined to think that both types of reacting may indicate difficulties in grasping the representational and symbolic function of images. 
These behaviors resemble the attitudes adopted during the interpretation of Rorschach test inkblots that were described by David Rapaport [12]. The first of these is the attitude of losing one's distance from the inkblots. It is the case when the examinee treats the inkblots as having one specific meaning that should be guessed. Such cases were also reported by Paluchowski [13], and my practice confirms the fairly frequent occurrence of this attitude. It may manifest itself in a less distinct form in embarrassment when giving another interpretation of a given inkblot or a part of it, or in comments such as: "This could be a branch, if this was not a human leg". The other attitude is excessive distance; it is the case when the examinee does not sufficiently consider the features of the inkblot and gives in to the stream of associations that are not anchored in the stimulus presented. Rapaport considers both of these attitudes to be something natural that may occur in every examination, but examinees should nevertheless be able to control them and be aware that they are dealing with signs that, on the one hand, permit a certain degree of latitude, but on the other hand require "realism" and a sense of reality.

Although the perception of images and the interpretation of inkblots may be more of less difficult, visual perception seems to be an easy and obvious activity, as I have mentioned before. Such impressions may be due to contemporary culture, which is filled with images. It can be said that we are suffering from their excess and, what is more, that images more and more often supplant words. Gilbert Durand says, metaphorically, that we are "choking on images" [14].

4. According to Rorschach and his contemporary Robert Vischer, seeing something in the inkblots involves the mechanisms of projection and introjection

Let us recapitulate: Rorschach created inkblots for the purposes of experimental research into broadly defined human perceptual experience. He followed his teacher Eugen Bleuler in assuming that perception was not passive observation or reflection of the world but a person's active participation in the world. In this perspective, perception consists in adjusting sensory data to the memory traces (engrams) already present in the mind. This adjustment encompasses a person's entire essence, cognition, affect, and physicality (corporeality). Researchers have not found information showing that Rorschach knew the views of his contemporary Vischer, but the understanding of perception found in these two thinkers is very similar. Drawing on Karl Albert Scherer, Vischer believed that perception consisted in projecting the mental and sensory ego into an object (projection). This projection is sometimes so intensive that the subject can be said, metaphorically, to "enter into" the contours of the object, as though they were putting on clothes made for them. This projection can be called a kind of "empathy". Rorschach spoke of empathizing that was particularly intense in the perception of movement. According to Vischer, empathy is not a one-sided phenomenon. The object functions like a soundboard - it reflects what happens between it and the subject, and thus, through a mechanism of introjection, it influences and changes the subject $[2,5,15]$.

\section{Charles Sanders Peirce's theory of signs and the sign nature of inkblots}

As I have suggested in Introduction, inkblots are a kind of signs, and this view seems to be generally accepted in the specialist psychological literature. I have encountered no extensive discussions of this issue, and it seems that, in Rorschach's case, resorting to semiotics may yield interesting results. In the present article I will draw on Peirce's theory, attempting to discuss the specific character of Rorschach's inkblots in its light.

5. Signs belong to the ontic order

Semiotics emerged from linguistics on the one hand and from the philosophy of logic on the other. Ferdinand de Saussure should be mentioned here as the most significant scholar in the field of linguistics, and Peirce should be mentioned as the most eminent philosopher, considered to be the father of contemporary semiology. Saussure viewed language as a universal and abstract system with internal organization (he is therefore regarded as the father of structuralism); he claimed that a sign was a combination of a concept (signifé) and sound (signifiant). These two elements strictly ad here to each other, and even though they are located in the mind (the concept and the trace of stimulus), they are pure abstraction, belonging to a superindividual linguistic system that exists in social consciousness - la langue. For Peirce, a sign is a product of a perfect mind, which means the psychologism of de Saussure's model is only ostensible; there is no place in it for the object (the world) or for the subject [16, 17, 18]. Opposed to Saussure's dualistic theory of the sign is Peirce's triadic theory of signs. According to the latter, a sign is a relationship linking three elements. The first one is the sign vehicle - the material base of the sign. The second element is the signified object, which is what the sign points to. The third element is meaning - the interpretant, which is the key element of the sign. The interpretant mediates between the medium of message (the sign vehicle) and the object, relating the former to the latter, but what is important, is that it always relates to the object only in a particular respect. A sign is never about simple substitution: it never replaces an object - it is always about representation, about relating only to a certain aspect of an object. Therefore, Hanna Buczyńska- 
Garewicz writes that a sign says both less and more about an object: it says less because it does not cover the entire knowledge about the object, and it says more because, focusing on selected aspects of the object, it brings in some new knowledge. This selective representation of the object reveals that a sign cannot be understood as a physically existing item. The object as a physically existing thing is not part of the sign and is not an element of the sign; the object is not constitutive of the sign. The situation is similar in the case of the interpretant. The interpretant is a significant element of a sign, but it must not be confused with the interpreter, the sign user, the sign recipient, or the subject; the subject, just like the physical object, remains external to the sign. The sign, as an entity independent of the subject and the object, has an ontic nature; it exists regardless of whether it is interpreted or not. Interpretation is a relationship between signs. "The interpretant of a sign is the realization of its meaning; it is the extraction of this meaning from the state of pure possibility and amounts to its revelation. The meaning of a sign manifests itself through a different sign." [19].

Interpretation constitutes the deepest nature of thought; however, thought is not an act of consciousness but an ontic fact and belongs to the objective world. Peirce introduces the concepts of external interpreter and external object. External object should be understood as everything that belongs to the really existing world. Despite the fact that a sign is superindividual and belongs to the ideal sphere, it is nevertheless oriented towards an external object; this orientation is constitutive of the sign. Peirce's conception of the sign is thus marked by cognitive realism (rather than epistemological immanentism). Although it belongs to the ideal, ontic order, thought is built over the object and reckons with the real world, and the meaning of the sign corresponds to the actual form of the object. As Buczyńska-Garewicz writes, Peirce assumes the unity of thought and the world, consisting in the common occurrence of the triadic relationship in both of these spheres. The same goes for external interpreter - the recipient of signs and the subject. Even though the interpreter remains outside the sign, the acts of thinking and the processes of semiosis taking place in a specific mind have the same structure as the process of nonmental, ontic semiosis. Ontic semiosis (all sign acts) is referred to as potential, while semiosis taking place in a specific mind is referred to as actual. The latter follows the ontic order of the world. It can be said that actual semiosis follows potential semiosis, and it is the latter that is prior, both chronologically and in terms of importance [20].

6. A sign demands to be interpreted in a different sign

One may have the impression that, by introducing the interpretant into the sign, Peirce introduced an element of spatiality. I believe it can be said that the concept of sign as a "flat" connection of signifé and signifiant has been "unsealed" by the relationship linking the sign vehicle to the object of the sign thanks to the third element: the interpretant. Buczyńska-Garewicz follows Peirce in stating: "Because every sign relates to its interpretant, which is also a sign, the outcome is a sign superimposed on another sign" [19]. Moreover, Peirce introduced an element of dynamism, also thanks to the interpretant. Just like the object is not accessible directly but only indirectly through the interpretant, the interpretant itself can be known only indirectly, through another sign, and this other sign is, precisely, the interpretant. This means the interpretant plays a dual role. It is a significant internal element of the sign, but at the same time it is also another sign, an interpretation external to this sign. Interpretant is not only the meaning of the sign, but at the same time it is that which points to the medium of the message (the sign vehicle) with the intention for it to be interpreted by a different sign, and it becomes this different sign itself. This can be visualized as an act of the interpretant doubling: it is the meaning of the sign and it is another sign. It can be said, metaphorically, that while it remains the meaning of the "parent" sign, the interpretant "breeds" a further sign. This means signs have their dynamics. The meaning of the sign - in spite of being its essence - is not an entirely internal element of the triad and is not "closed up" in it. Again, using a metaphor, one can say that the meaning of a sign "pours out" of the sign in some way and "peeks out" from the sign triad.

7. A sign exists only in a system of other signs and is a link in the process of perpetual semiosis

As a result of the interpretant's activity, every sign requires the existence of another, prior sign that it can be an interpretant for, and it also requires a further sign that will in turn interpret its meaning. The need for perpetual interpretation stems from fragmentariness - from the fact that a sign relates to an object only in a certain respect and concerns only a selected aspect of the object. BuczyńskaGarewicz writes that the interpretant not only links the sign vehicle with the object of the sign but also links the sign with other signs, which results in a kind of élan vital of the world of signs operating in the sign system, bonding it together and developing it $[16,19]$. It is impossible for a sign to exist outside the system of signs. Signs have their "interpretability" and their "translatability"; they cannot stop their activity and must generate further signs. Following the potential interpretive acts, the subject is, in a way, forced to participate in the process of perpetual semiosis; again, let me use a metaphor and say that signs "attract" or "seduce" the subject.

8. The object demands interpretation, and the meaning of the world reveals itself to the subject 
As mentioned before, a sign (thought) as theorized by Peirce belongs to the ideal sphere but is oriented towards an external object, and this orientation is constitutive of the sign. It can, therefore, be concluded that thought and the sign are secondary to and built over the objective being; they do not produce it but are subordinated to the world, despite their autonomy. Like the internal interpretant, the external interpretant does not produce meaning but recognizes it; as Buczyńska-Garewicz writes, it is the way in which the understanding of the sign manifests itself $[16,19,21]$. We know this situation from our own experience: we feel that the meaning of signs is not an arbitrary product of our self but something given to us and offered to our self. Just like a sign demands interpretation, the object desires to acquire its meaning and to find its signification. What is interesting for psychologists using the Rorschach test is the observation made by Wojciech Kalaga, illustrating the object's striving to become a sign. This author refers to the situation of wax divination, which is, after all, nearly the same as interpreting inkblots: "in a traditional game of wax divination, the emerging shape - according to the rules of this game - requires to be granted meaning" [20].

9. Some characteristics that Peirce attributed to signs are visible in the situation of examination using the Rorschach test

The meanings hidden in inkblots can be regarded as an infinite set of various observations that require interpretation. This is the perspective experienced by a psychologist using this test. Years of using it bring more and more nearly identical responses, but it is never the case that new, original interpretations cease to occur, however rarely. The experience of this situation is accompanied by surprise and amazement: how is it possible that so heavily "worn out" stimuli are still capable of showing their another hitherto unknown side? It can be said that - by a twist of fate, as if unintentionally - Rorschach actually illustrated the functioning of signs as described by Peirce.

Firstly, it is evident how inadequate the successive meanings extracted from a sign (an inkblot) are and how they fail to do justice to the full diversity of meanings present in it. Secondly, the most frequent reaction to the situation of inkblot interpretation is the examinee's excitement and engagement. One may have the impression that the examinee succumbs to the pressure of signs demanding to be interpreted and feels intrigued by some kind of anticipated mystery hidden in the inkblots. Sometimes it happens that a potential examinee refuses to do the test or exhibits negative emotions, usually in the form of criticism of the test. In my opinion, such behaviors are a defense mechanism applied in order to avoid situations of uncertainty, or they stem from a different situation of the examinee, external in relation to the inkblots, not linked with their nature and irrelevant to the process of semiosis. The person interpreting inkblots usually has the impression that he or she is "discovering" rather than creating the images they contain. At the subconscious level, this last experience may give a sense of participation in the ontic order of the world.

\section{The phenomenology of perception and the interpretation of inkblots}

As already mentioned, Rorschach's main interest was perception, especially the perception of movement. Akavia reports that, according to Rorschach, observing dynamism in a static inkblot was not an illusion but an expression of subjective experience. She points out the similarity of the Swiss psychiatrist's views to the views of his contemporary phenomenologist Edmund Husserl. For the latter, the human mind is an "intentional force," processing sensory data in a subjective source experience of meaning. Moreover, what plays a fundamental role in this experience is kinesthesia, constituting the core of subjectivity and a condition for the development of the self. Likewise, Rorschach speaks of "empathizing" when perceiving movement, which implies the involvement of the body in this perception. In Husserl's phenomenology, the body plays an important role in sensory perception. This philosopher speaks of a visual, tactile body and about a body of will and kinesthesia; the latter constitutes the "center" of the subject and allows for the emergence of intersubjectivity and objectivization of cognition. It should be noted that Husserl was far from psychologism, and his reflections concern the transcendental order [19, 22]. Having analyzed the available sources, Akavia is inclined to conclude that Rorschach did not know Husserl's writings. In her 2000 article [23], Helen Malmgren mentions another phenomenologist, Maurice MerleauPonty, whose first book, La structure du comportment, came out more than twenty years after Rorschach's death. The views of this French philosopher were most clearly presented in a work entitled Phenomenologie de la perception. One may have the impression that if Rorschach had continued his reflections on perception he would have had to follow a path similar to Merleau-Ponty's, or even that the originator of inkblots could be regarded as one of the unnoticed and forgotten precursors of the concept of "embodied perception" (apart from Vischer and Scherer). The similarity of Rorschach's and Merleau-Ponty's thought seems to be so significant that the lack of a thorough analysis of this phenomenon is surprising.

10. According to Merleau-Ponty, projection and introjection are important mechanisms involved in the process of perception

Merleau-Ponty's main point is that perception requires a fusion of the subject and the object and that it 
is the fulfillment of the motor projects projected on the objects perceived. Motor projects involve a part of the environment - which means this is a case of projection. This "involved" part of the environment is, in turn, included in the body schema, which means a mechanism of introjection is also at work here. The perceiving organism and its environment overlap [24, 25]. As we can see, both according to Rorschach and according to Merleau-Ponty, perception is possible thanks to the subject's activity, thanks to the subject going out into the world and responding to the world's call to assimilate it. Let us say, using a metaphor again: the subject unites with the world the way an organism unites with its food, transforming it into its own tissue. Jacek Migasiński writes about MerleauPonty's view of perception as follows: "Perception is thus the external fulfillment of my meaning-making potencies; it is a unification of my body with things, a kind of 'communion with them"' [25]. A similar "voracity" in rapture over the visual magnificence of the world is found in Rorschach. It is observed by Searls [5], who cites Rorschach's favorite poem by Gottfried Keller. The last two lines of this poem (as cited by Searls and translated into English) read:

Drink in, oh eyes, all your lashes can hold

of the golden abundance of the world.

Och oczy! Spijajcie aż do dna samego

Całą ta obfitość świata wspaniałego!

[tłum. własne autorki]

11. The body and perception are considered as transcendental beings

The central topic in Merleau-Ponty's phenomenology is the body. The body is the point from which a person looks at the world, and it is the body that makes human experience of the world possible. It is this experience that the French phenomenologist's entire philosophy is based on. It shows the world undistorted by any reflection: "Everything that I know about the world, even through science, I know from a perspective that is my own or from an experience of the world without which scientific symbols would be meaningless" [24]. The pure description of this experience is a return to things in themselves, from before cognition, excluding the achievements of science, which presents the world in an abstract manner, using signs.

As Migasiński observes [25], before taking the chair of philosophy at the College de France, MerleauPonty was head of the Psychology and Education Department at the Sorbonne. Therefore, many pages in the French philosopher's texts are devoted to detailed psychological analyses of perception and to descriptions of psychological experiments involving psychopathology. Merleau-Ponty avoids psychologism, however; he aims at what is universal and gives the body and perception an ontic status. According to him, the world is exactly what the subject presents to themselves, but the subject does this as an equal participant in a single, indivisible world. Even though for every subject the experience of the world is "their own" experience, it is at the same time fully anonymous from the beginning, it carries general structures with it, and contact with the object is not a tool but a core component of consciousness, identical with other people's experience; the individual's consciousness does not differ in any way from "other" consciousness, as everyone is directly present in relation to the world. In every subject the perception of the world is not an individual's work but the work of prepersonal consciousnesses, which makes intersubjectivity the foundation of social relations. "Perception as a link with being creates the ontological framework for the constitution of the world's reality prior to all theoretical thought [25].

12. The world appears to the subject and demands to be present in the subject's consciousness

In the preface to his Phenomenology of Perception, Merleau-Ponty writes: "The real is a tightly woven fabric; it does not wait for our judgments..." [24]. The subject does not construct the world; on the contrary, it is the subject who is "given up" to the world". The world is a "natural" environment and setting of all thoughts and all my clear perceptions, and it is the world that precedes all analysis. The French phenomenologist makes a reservation here: the world is not what we think but what we perceive [24]. The real has an ontic status, and the subject experiences it, living the world.

The subject experiences the world thanks to the body, which, as has been stated before, also belongs to the ontic order. It is the body that constitutes a person's general way of communicating with the world and affords a certain degree of possessing it - a "certain degree," because according to Merleau-Ponty, the world is inexhaustible by nature [24]. The body is equipped with certain motor abilities and certain powers, which, however, amount to intentionality - orientation towards the world - rather than to simple physical power. The subject is able to project motor projects outside, as a result of which the world acquires new meanings. It is thanks to the body that the subject becomes an intentional and active being, and it is thanks to the body that new meanings and senses manifest themselves in the subject's consciousness. It is the body that penetrates the environment and links it with things. Perception is always "embodied cognition"; it apprehends the world by clinging to things, and it is more than cognition: it is our "belonging" to things, and conceptual knowledge is always rooted in this first, nonreflective, corporeal "knowledge" about the world. Being is always apprehended from some corporally determined 
perspective. One can hardly fail to notice that this openness to the world and going out into the world is at the same time the subject's expression and the materialization of new meanings in the world.

According to Merleau-Ponty, the source of consciousness is the sense of "I can" rather than "I think." "I can" manifests itself in projecting motor projects, in adopting an active attitude to the world, and in orienting oneself to the sphere of possible perceptions and possible actions. Perception and expression determine the relations that link the subject with the world. It can, therefore, be said that the subject communicates with the surroundings and responds to the world's appeal, while the world demands to be present the subject's self, to be described and experienced.

13. The object is always considered in the context of other objects and perception is a perpetual process

According to Merleau-Ponty, although perception is direct and non-conceptual cognition, it never apprehends the entire truth about the object. In the first phase of looking the sight grasps the whole view in front of the eyes, and then the glance falls on a selected fragment of the field of vision - on a selected thing. The selected object livens up and seems to develop, while the remaining objects withdraw to make up the background. To look at an object is to place oneself in it and to look at other objects from its position. I can see other objects only as the object I previously selected allows me to see them, and only in such a way as it can "see" these objects. But the other objects also become my loci, and I look from their perspective at the thing that was my first interest as well. Thus, every object within my field of vision becomes a mirror for other objects. I see the selected object from many sides, as my own position and the position of other objects allows me to. It can, therefore, be said that an object can be perceived thanks to the fact that it is placed among other objects and is an element in an entire system of things - part of the world of things. My gaze, however, can never grasp a given thing at every possible angle. When new but incomplete knowledge appears, the subject is motivated to engage in further actions in order to complement this knowledge at least to some extent and to remedy its fragmentariness. Despite these efforts, the object will never appear in the subject's consciousness in its whole truth. An object that would appear in all its completeness would be an ideal object. Merleau-Ponty describes it as follows: "The fully realized object is translucent, it is shot through from all sides by an infinity of present gazes intersecting in its depth and leaving nothing there hidden" [24]. The world appears to the subject as incomplete and "fragmentary"; this fragmentariness of the world becomes an appeal for further efforts, and the subject responds to that appeal.
"To see is to enter into a universe of beings that show themselves, and they could not show themselves if they could not also be hidden behind each other or behind me" [24].

14. Merleau-Ponty's phenomenology of perception is an unintended but strikingly consistent complement to and elaboration of Rorschach's views

Both for Rorschach and for Merleau-Ponty, perception is a subjective experience made possible by the subject's activity and accomplished through the mechanisms of projection and introjection. Rorschach speaks about the interiorization of perceived movement (introjection) and about projecting it on the static inkblot (projection). Merleau-Ponty claims that perception is possible thanks to the ability to "grasp" the world in motor projects: the subject places themselves in the object and "anchors" themselves in it [24], and part of the environment appropriated through motor projects becomes incorporated into the body schema (introjection). For both of these thinkers, by absorbing the world and actively experiencing it, subjects express themselves in their subjectivity; perception is linked with expression, and perception is an experience. Migasiński points out that according to the French phenomenologist, it is the body that enables the unity of the experienced world and the subject - the unity he terms "presence." Akavia refers to Rorschach's model of perception as "embodied perception," using a term that seems to be reserved for Merleau-Ponty [2]. She also stresses the significance of the concept of intersubjectivity in Rorschach's understanding of perception: for him, subjectivity is individualized, marked by a subjective, personal, emotional, and embodied history [2].

The two thinkers discussed here are also united by a fascination with movement, which amounts to expression experienced thanks to the body. The literature often mentions Rorschach's dream which is a reminiscence of the first time the author of inkblots took part in an autopsy. In this dream he experienced a distinct, overwhelming, and almost physical impression that his own brain was being sliced. What is more interesting than the dream itself, however, is its interpretation offered by Rorschach, who realized that visual perception could be transformed into bodily experience [5].

The perception of movement in a static inkblot was the most interesting thing for Rorschach. He analyzed responses determined by the shape of inkblots, by their color, and by the shading visible in them, but he considered movement responses to be expressions of the individual's most personal and deepest experiences and believed that it was these responses that revealed the essence of the self. Discussing the spatial nature of the body and motricity, 
Merleau-Ponty writes: "Our body [...] is the origin of all the others, it is the very movement of expression, it projects significations on the outside by giving them a place and sees to it that they begin to exist as things, beneath our hands and before our eyes" [24]. For this phenomenologist, the body is "an expressive space" and a general way of knowing the world. The significance of movement is underscored by his quotation from Albert S. F. Grunbaum: "Motricity is the primary sphere in which the sense of all significations (der Sinn aller Signifikationen) is first given in the domain of represented space" [24]. Thanks to motricity, a person becomes aware of own body and its place in the world; it can, therefore, be said that, on this basis, it is possible for a person to experience oneself and, consequently, for the self to develop.

The above similarities between the views of the two authors discussed here are not invalidated, I believe, by the difference in their understanding of the nature of the subject and cognition. Rorschach probably treated perception as a psychological phenomenon, and more general philosophically considered problems were probably not so important to him. For Merleau-Ponty, by contrast, as I have already mentioned, the subject was anonymous and "transcendental"; the philosopher attributed a universal nature to the subject, and he believed that perception, as a link with being, created the ontological framework for the constitution of the world's reality. But what seems to be the most important in the comparison of the two thinkers is that they both write about perception as active and expressive penetration of the world, close contact of the subject with the world, and their mutual influence. They are also united by the acknowledgment of the significant role of the body in perception. According to Merleau-Ponty, perception is fundamental for exploring the world; all knowledge, even that which is coded in signs, is anchored in perception. Rorschach, who makes perception his main object of interest, seems to share this view.

\section{Rorschach and Merleau-Ponty vs. Peirce: similarities and differences}

15. Although at first glance Peirce's theory of signs is totally different from the theory of cognition developed by Merleau-Ponty, the similarities between the views of the American semiotician and the French phenomenologist do exist and can also be related to Rorschach's thought

Peirce's theory of signs is focused on meaning, whereas Merleau-Ponty and Rorschach were interested in perception understood as a form of experience - a way of experiencing the world.

Peirce occupies a separate place in my reflections presented here: focused on signs, he believed that only indirect cognition was valuable, even though it was always fragmentary and incomplete. Merleau-Ponty understood perception in an original way and denied its capability to grasp the whole truth about an object.

The first similarity between Peirce and MerleauPonty can thus be seen: the estimation of human cognitive abilities is similar in these two philosophers. Moreover, the incompleteness of cognition is a motive for repeating cognitive acts. In Peirce, a sign requires interpretation in a different sign. Thought seeks the truth in a never-ending process of semiosis, and the subject follows the objective ontic order of interpretation, giving in to the pressure of signs. Likewise, in Merleau-Ponty perception does not grasp the whole object; due to the infinite number of possible directions from which we look at a given object, cognition must take place gradually, in successive acts of perception, and apprehending the whole truth is a goal that can never be accomplished.

It must be conceded that in Peirce's theory the final aim of cognition is the whole truth about the object, whereas the French phenomenologist accepts the incompleteness of cognition.

The next similarity in the thought of the two philosophers lies in their rejection of psychologism and in the view of cognition as belonging to the ontic side of the world (Peirce) or to the universal domain, transcendent in relation to the cognizing subject (Merleau-Ponty - in the thought of this philosopher, the ontic level of cognition receives much less emphasis). Personally, I consider it possible that the subject realizes, if only at the preconscious level, that even though contact with the world is his or her personal experience, it is at the same time identical with the transcendental and intersubjective experience belonging to the ideal order. Further, it should be stated that according to both philosophers, the subject must be active; it must yield to the pressure of signs, as the semiotician says, or, as the phenomenologist says, must respond to the world's call. Next, it should be stressed that, despite the subject's active attitude, it is not the subject who creates the world but it is the world that reveals itself and lets itself be discovered. This revelation of the world and the awareness that the truth revealed about it belongs to a higher, ideal order may, I suppose, give a sense of participation in a true and real world. Both philosophers stress that cognition can take place only in systems (in Peirce these will be systems of signs, while in Merleau-Ponty they will be systems of things) and that these systems are characterized by dynamism. In Peirce, the interpretant unites the world of signs and is the élan vital of that world, while in Merleau-Ponty what can be regarded as the force uniting the world is the intentionality of the human mind, responding to the call of the world, and projecting motor projects on the world. 
In my opinion, the similarity of the presented philosophical theories to Rorschach's thought should be sought, above all, in the emphasis placed on the significance of kinesthesia. The Swiss psychiatrist's preoccupation with movement may correspond to the subject's active attitude in Merleau-Ponty and to the activity of signs themselves, "demanding" interpretation and "carrying the subject away," so to speak, into a sequence of cognitive acts. Also important is the view of movement perception as a result of identification with the object - with the inner bodily response that accompanies visual perceptions. This transformation of visual sensations into bodily sensations can be treated as uniting with the surrounding environment, which Migasiński - discussing Merleau-Ponty's thought - refers to as communion with the world. Both Rorschach and the French phenomenologist emphasize the role of the body in cognition. Rorschach did not have enough time to elaborate his theory of perception, but he did clearly underscore his view on experiencing the world, marked by intensity and a kind of "voracity."

In my opinion, the experience of the world as presented by Rorschach can be compared to the dynamism of the sign system in Peirce.

16. Indirect thinking and direct thinking complement each other

Buczyńska-Garewicz observes that while direct thinking links a person with the world, thinking through signs may separate him or her from the world and increase the distance between the cognizing subject and the object of cognition. She firmly underscores the view held by Peirce, who claims that indirect cognition, taking place through signs, is the only reliable cognition; thought can be realized only in signs, which means direct, evident cognition is not possible. The experience of evidentness and intuition have no cognitive value. To use the terminology adopted by the father of phenomenology, Husserl, cognition takes place through acts of direct apprehension of meaning. These acts are either intellectual insight, in which the apprehension of meaning takes place by grasping the identicalness of meaning in abstracto and enables knowing the object in all its truth, or acts marked by evident concretization, acts in concreto, which, however, are not part of the essence of cognition but merely supplement it [19]. Merleau-Ponty views perception differently. In his work, perception is always filled with the experience of the world; it is anchored in the body, does not provide insight into full meaning, is always fragmentary, and requires repeated cognitive acts. However, it is perception that the French phenomenologist considers to be the essence of cognition, and all other types of cognition (whose existence he does not deny) have their source and their necessary basis in perception.
Buczyńska-Garewicz challenges the clear-cut distinction between two types of thinking: indirect and direct [15]. This issue is important for the discussion presented in this article, as the Rorschach test was meant to be a test investigating perception, whereas in this case it is postulated that the inkblots have the nature of signs and that examinees approach the interpretation of inkblots as the interpretation of signs. BuczyńskaGarewicz draws attention to the otherwise obvious fact that cognition through signs requires the perception of the sign vehicle and to a certain property of perception discussed in the literature devoted to it - namely, to the fact that perception is not mechanical: "From the very beginning, the perception of the material medium is entangled in sign interpretations and regarded as a path to knowing something hidden behind and distinct from the medium" [16]. Similarly, the reception of the inkblots must engage perception, but it is obvious to everyone who looks at them that they are not things but their representations - signs. One can say that cognition through signs can be supplemented by direct thinking, which may become the background for it. Nor must one forget about the view held by art historians, who studied perception and concluded that, in essence, perception was visual thinking [6]. It is not without significance for the present discussion that both Rorschach and Merleau-Ponty understood perception very broadly. For Rorschach, it was a complex process, a mixture of affect and cognition, engaging the entire person together with his or her physicality. Peter Galison proposes to understand the Swiss psychiatrist's thought as implying that perception is related to interpretation the way genus is related to species, which means it should be concluded that, for Rorschach, perception was the basic cognition on whose background, and not otherwise, cognition through signs could appear. Galison quotes a passage from Psychodiagnostics (as translated by Paul Lemkavu and Bernard Kronberg): “...the differences between perception and interpretation are dependent on individual factors, not on general ones; that there is no sharp delineation, but a gradual shifting of emphasis; and that interpretation may be called a special kind of perception" [26]. Also for the French phenomenologist perception is the essence of human cognition - the essence of human existence, one might say. Like Rorschach, he treats it in a special way, saying: "the 'immediate' [...] is no longer the impression or the object that merges with the subject; rather, the immediate becomes the sense, the structure, and the spontaneous arrangement of parts" [24]. Moreover, as we remember, Merleau-Ponty saw the insufficiency of perception: it is direct cognition, but it fails to meet the basic condition for direct thinking namely, grasping the object in its full truth. John Lechte [27] suggests that Merleau-Ponty was aware of the 
"fraction" in his philosophy between lived experience and thought. Buczyńska-Garewicz points out that interpreting does not have to be limited to the intellect, since emotional and volitional interpretation is also possible. One may have the impression that also Peirce tried to overcome the one-sidedness of his theory by introducing additional interpretants - e.g. emotional and energetic ones. These interpretants are effects evoked by a sign in someone who perceives and interprets this sign. Following this path distorts Peirce's thought, however. The American semiotician was aware that a sign was linked not only with a logical interpretant, but he firmly stressed that all interpretations of a sign except the logical interpretant were elements degenerating the sign and depriving it of the fulness of its nature [19]. One can, therefore, do nothing but accept that Peirce was interested only in the ideal, general, and timeless being, and that for him semiotics was, simply, logic [19]. Discussing sensory perception issues, Stanisław Judycki writes that its nature is so complex that so far no satisfactory explanation of this type of cognition has been provided and that this diagnosis concerns knowledge in the field of natural sciences, the philosophy of mind, and general philosophical reflection alike [22]. Assuming that the problem of human cognition is one of the fundamental philosophical issues, I believe it should also be assumed that, like other key philosophical questions, they are virtually unresolvable, though at the same time they cannot be abandoned without detriment to human thought and culture. I believe that, in the light of the presented reflections, both types of cognition should be treated not only as cognition in the strict sense of the word but also as forms of experiencing the world and one's place in this world, and that these two forms of cognition complement each other. It is also possible to follow the line of thinking proposed by Buczyńska-Garewicz, who concludes that semiotics rises above the traditional division of the mind's abilities and blurs the border between its powers [16]. Interpretation, as an important element of a sign, can be treated as a multidimensional phenomenon, and this diversity would concern both the meaning and the sign vehicle. In that case, it would also have to be assumed that interpretation, as a higher order category, is a significant way of experiencing the world and a significant form of contact with the world. We may therefore add another term to the list of expressions referring to man, namely: "the interpreting man."

\section{Conclusion}

Finally, it seems reasonable to reflect on what significance of the above discussion has for a practicing psychologist. I believe that a deeper understanding of the nature of the instrument one uses in examinations is never superfluous. The examinee's and the examiner's engagement may stem not only from their personal attitudes but also from the specific character of the applied stimuli. A psychologist should be aware that the situation of examination using the Rorschach test may intensify the way in which the examinee approaches the world and may reveal the examinee's two basic experiences in grasping the world: the experience associated with perceiving the world and the experience associated with interpreting the world. As I have attempted to show, these two ways of experiencing the world are not alternative to each other but interpenetrate each other. If we assume that interpretation is not only an epistemological category but also an ontological one, then it should also be assumed that our interpretive activities amount to the realization of ontic intersign interpretation. The situation of examination using the Rorschach test thus acquires an existential dimension; it shows the essence of human functioning in the world, and the examinee's and the examiner's positions become the positions of partners, belonging to the same level.

\section{Wstęp}

We wrześniu 1921 roku ukazała się w Bernie monografia zatytułowana Psychodiagnistik, w której jej autor, Hermann Rorschach, zaprezentował dziesięć tablic z plamami atramentowymi, mającymi - w zamyśle ich twórcy - służyć do eksperymentalnego badania percepcji. Bardzo szybko jednak stworzone przez szwajcarskiego psychiatrę plamy zaczęto traktować jako test psychologiczny sensu stricto. Tendencja ta nabrała intensywności około 1926 roku, gdy tablice Rorschacha zaczęły być coraz popularniejsze w Stanach Zjednoczonych. Były to też lata żywiołowego rozwoju psychometrii, który to fakt zaowocował różnymi próbami uczynienia z metody Rorschacha testu spełniającego kryteria mierzalności i ścisłości. Taki sposób traktowania tablic stał się jednak zarazem źródłem, niekiedy bardzo ostrej, krytyki testu jako nie dającego w miarę zobiektywizowanej wiedzy o badanej osobie. Nie sposób odmówić zasadności wielu takim zastrzeżeniom, trzeba jednak zaznaczyć, że jednocześnie zaczęły się pojawiać coraz to nowe próby wypracowania dla tego testu mierzalnych kryteriów.

Nie da się zaprzeczyć, że badanie za pomocą plam Rorschacha może być źródłem istotnie cennych informacji o badanej osobie, podobnie jak bardzo wartościowym źródłem takich informacji są inne swobodne metody jak np. psychorysunek czy rozmowa.

W przypadku testu Rorschacha niezwykle frapujący 
jest natomiast fakt, iż jego fenomen wykracza poza utylitarną wartość badania psychologicznego: test ten można i należy traktować także jako zjawisko kulturowe, intrygujący przedmiot możliwych badań i refleksji dla każdego zainteresowanego szeroko pojmowaną humanistyką. Może on zająć myśl badacza znaków, jak i kogoś, kogo interesują zagadnienia percepcji. W rezultacie test Rorschacha staje się czymś więcej niż tylko, aprobowanym czy nie, testem do badania klinicznego: jest szerszym zjawiskiem, nad którym refleksja może dać to, co w końcu najcenniejsze: lepsze poznanie natury ludzkiej.

Osobiście jestem przekonana, że test ten nie tylko odsłania tę warstwę psychiki, którą nazwę warstwą psychologiczną, a co więcej - porusza głębsze pokłady przeżyć danej jednostki, wiążące się z jej doświadczeniem świata i swojego w nim miejsca i jest cennym materiałem zarówno dla badaczy znaków, jak i dla badaczy percepcji.

W niniejszym artykule będę chciała omówić podwójny charakter plam Rorschacha: jako testu „odgadywania” znaczenia znaków i jako testu badającego percepcję.

W pierwszym ustępie skupiam się właśnie na specyfice plam, ukazując ich podwójną naturę: są one przedmiotem percepcji, a zarazem znakami, „domagającymi się” odkrycia swoich denotatów.

Znakowy charakter plam, choć zauważony, nie był dotąd przedmiotem bardziej szczegółowej analizy. W moim przekonaniu problem ten bardzo owocnie można rozważać, przywołując teorię znaku Charlesa Sandersa Peirce'a. Temu zagadnieniu będzie poświęcony ustęp drugi tego artykułu.

W ustępie trzecim zajmuję się plamami Rorschacha jako przedmiotem percepcji, zwłaszcza w świetle fenomenologii percepcji Maurice’a Merleau-Ponty'ego. Poza jedną wzmianką w kontekście Rorschacha (u Helen Malmgren) nie spotkałam w literaturze żadnych omówień tej problematyki.

Ustęp czwarty jest próbą „ujednoliconego” spojrzenia na test Rorschacha: jako na test badający percepcję i jako na test „odgadywania” znaczeń znaków.

We Wnioskach podkreślam znaczenie testu Rorschacha jako testu poruszającego uniwersalne przeżycia człowieka związane z ogólnie pojętą kondycją ludzką.

\section{Natura plam i ich recepcja}

1. Stworzone przez Rorschacha plamy atramentowe cechuje doskonała harmonia między tym, co znane a tym co nieznane, jak i między tym, co zorganizowane a tym co zupełnie swobodne

Jeśli pominiemy psychologiczne metody projekcyjne oparte na analizie wytworów badanej osoby (np. psychorysunek), możemy powiedzieć, że plamy stanowiące test Rorschacha są najsłabiej ustrukturyzowanym materiałem wśród innych bodźców stosowanych w badaniach psychologicznych. W związku z tym przyjmuje się, że wszystko, co badany zobaczy w plamie, jest wynikiem czystej projekcji, skutkiem rzutowania na nią własnej psychiki.Źródeł takiej postawy można upatrywać w stwierdzeniu samego Rorschacha, że plamy powstały poprzez „rzucenie” farby na kartkę papieru (był to rodzaj bibułki), a następnie złożenie tej kartki na pół. Utworzony w ten sposób bodziec z konieczności musiałby mieć - poza symetrią - charakter przypadkowy, arbitralny. Warto jednak zwrócić uwagę także na inne wypowiedzi autora testu. Twierdził on np., że plamy powinny spełniać pewne warunki dobrej kompozycji, a co ważniejsze, że mają być podobne do wielu rzeczy, których obrazy, czyli engramy, zakodowane są w ludzkich umysłach. W rzeczywistości było tak, że szwajcarski psychiatra dokonywał wielu zmian w plamach w ten sposób, by spełniały one jego oczekiwania [1]. Naamah Akavia - opierając się na pracy historyka sztuki Dario Gamboniego - podkreśla, jak usilnie pracował Rorschach nad plastycznym wyrazem swoich tablic, np. jak bardzo zabiegał o to, by utrzymać odpowiednią waloryzację kolorów ( światłocień) [2].

Można powiedzieć, że plamy nie przedstawiają niczego konkretnego w sposób dostatecznie czytelny, a jednak kryją w sobie obrazy wielu rzeczy, które można z nich wydobyć. Zauważa to Władysław Paluchowski, pisząc, że plama to zbiór modeli przedmiotów rzeczywistych [3]. Idąc dalej należy przyznać, że niektóre z tych modeli łatwo jest odkryć, że nierzadko narzucają się one niejako wprost, podczas gdy inne trudniej jest ujrzeć i wymaga to większego wysiłku. Te oryginalniejsze i niełatwe do wydobycia obrazy mogą być słabiej uzasadnione cechami danej plamy, ale bywa i tak, że okazują się one bardzo do nich adekwatne. W każdym systemie interpretacyjnym psycholog ocenia adekwatność wypowiedzi badanego, co wskazuje na pewną obiektywność znaczenia plam. Na ogół przyjmuje się, że plamy nie mają znaczenia denotacyjnego, a jedynie znaczenie konotacyjne, emocjonalne [4], nie są bowiem obrazkami przedstawiającymi jakąś jedną rzecz. O znaczeniu denotacyjnym mówimy wówczas, gdy znak wskazuje jasno na jakiś przedmiot lub pojęcie. O znaczeniu konotacyjnym mówimy wtedy, gdy mamy do czynienia z dodatkowymi skojarzeniami, które znak wywołuje, zwłaszcza z takimi, które mają zabarwienie emocjonalne. Trzeba zaznaczyć, że te dodatkowe odczucia nie są bezpośrednio związane z zakresem znaczeniowym pojęcia.

Jak pisze John Exner, plamy testu Rorschacha posiadają pewne cechy (critical distal bits), uprawniające do jednych interpretacji, a dyskredytujące inne. Możemy powiedzieć, że plamy są znakami wieloznacznymi, o 
szerokim zakresie możliwych interpretacji. Plamy nie są bodźcami amorficznymi, lecz bodźcami, które mają swoją strukturę i określone cechy formalne. Ustrukturyzowanie plam podkreślają zwłaszcza ci psycholodzy, którzy aktywność badanej osoby pojmują przede wszystkim jako aktywność poznawczą, a samo badanie testem jako swego rodzaju sytuację decyzyjną związaną z rozwiązywaniem problemów. Znaczenie organizacji dającej się zauważyć w plamach podkreśla Paluchowski: „istotą czynności badanego nie jest selekcja napływających skojarzeń, ale także aktywne wyodrębnianie z plamy tego, co jest podstawą werbalizacji" [3]. Autor ten zauważa, że nie wszystko jest projekcją. Wypowiedzi badanego uwarunkowane są przecież nie tylko jego indywidualnymi cechami, ale także cechami plamy, należy więc rozróżniać, co jest właściwością samej percepcji charakterystycznej dla badanej osoby, a co stanowione formalnymi cechami bodźca. Na pierwszy rzut oka wydaje się, że plamy są arbitralne, a jednak można w nich odkryć ukrytą strukturę; wydają się symetryczne, a jednak nierzadko łatwiej jest spostrzec jakiś obiekt w jednej połowie plamy niż w drugiej; wydaje się, że nie przedstawiają niczego konkretnego, a jednak kryją w sobie wiele denotatów. Narzuca się spostrzeżenie, że bodźce omawianego tu testu charakteryzują się zrównoważeniem sprzecznych właściwości. To, co badany dostrzeże w plamie, uwarunkowane jest jej cechami, ale które cechy i w jakiej konfiguracji zostaną wybrane, nie jest łatwe do przewidzenia. Damion Searls pisze: „Rorschach inkblots are like the act of seeing, which itself has both structure and latitude. There's something realy there, but not anything that constrains us completely. The visual nature of the world is objectively in things, but we see it there; we subjectively impose our view of the world onto things, but only if that view fits what we see. We're all looking at the same thing, even when we see it differently” [5]. „Plamy atramentowe Rorschacha przypominają sam akt widzenia, który jest ustrukturyzowany i swobodny zarazem. Coś rzeczywiście stoi przed naszymi oczyma, ale nie jest to nic co ograniczałoby nas całkowicie. Wizualna natura świata tkwi w rzeczach obiektywnie, lecz to my je widzimy; subiektywnie projektujemy na postrzegane rzeczy naszą wizję świata, ale tylko w takim stopniu, w jakim one do tej wersji pasują. Wszyscy patrzymy na to samo, nawet gdy widzimy to odmiennie" [ tłum. własne autorki].

2. Różne sposoby interpretowania plam są w dużej mierze uwarunkowane ich specyfiką jako bodźców

Ciekawe, że formalne cechy plam analizowali historycy sztuki. Psycholog, ale przede wszystkim teoretyk sztuki i filozof Rudolf Arnheim pisał: „reakcje na całkowicie amorficzne bodźce są słabe i pozbawione sensu. Aby umysł zareagował rozpoznaniem formy, niezbędna jest bogata kolekcja wyraźnych, lecz dwuznacznych wzorów, taka jak zbiór plam atramentowych z testu Rorschacha. Rozpoznanie zakłada obecność czegoś, co można rozpoznać" [6]. Arnheim przeprowadził analizę znaczeń zakodowanych $\mathrm{w}$ formalnych cechach plam. Wyniki tej analizy w odniesieniu do pierwszej tablicy testu referuje Searls. Okazuje się np., że możliwe są różne ujęcia wewnętrznej organizacji plamy [5]. Moja wieloletnia praktyka $\mathrm{w}$ stosowaniu testu Rorschacha potwierdza, że niektóre z takich wewnętrznych struktur plam jakby same narzucają się badanemu, inne zaś nie jest łatwo "wydobyć".

Właściwości plam nierzadko prowokują przeciwstawne odczucia i interpretacje. Jako przykład podam dziesiątą tablicę testu. Tablica ta często wywołuje wrażenie nadmiernej różnorodności i chaosu, utrudniających znalezienie odpowiedniej interpretacji. Oto reakcja trzydziestolatka na tę tablicę: „O jejku, tu strasznie kolorowe i bardzo rozprasza, trudno zobaczyć dokładnie". Natomiast dwudziestoczteroletnia studentka odebrała tablicę dziesiątą jako doskonale zorganizowaną przestrzeń. A oto jej wypowiedź: „Ogród, piękne trawniki, klomby z kwiatami położone po obu stronach symetrycznie, zadbane, kolorowe, robi piękne wrażenie" [7]. Ważne i intrygujące jest to, że zarówno wrażenie chaosu, jak i odczucie uporządkowania mają swoje uzasadnienie w strukturze plamy. Nawet spostrzeganie ruchu, które często traktuje się jako wyraz czystej projekcji [8], może być uwarunkowane „zwykłymi” cechami plamy. Jak wskazuje Arnheim, wystarczy np. ukośne ułożenie elementów lub ich klinowy kształt, by obraz emanował dynamiką [9]. Zdarza się też, że kształt plam sugeruje sprzeczne treści. Przykładem może być tablica trzecia, na której często widziane są postaci ludzkie, ale kształt głów tych postaci może jednak przywoływać także obraz głów ptaków albo zwierząt z wydłużonym pyskiem. Najczęściej badani nie zauważają tych dodatkowych możliwości, ale bywa, że pojawiają się tu wypowiedzi typu: „, to mogliby być ludzie, gdyby kształt ich głów nie przypominał ptaków".

Czasami badani łączą dwa obrazy ( "to są ludzie jakby z dziobami"), ale pozostają krytyczni wobec swojej interpretacji. Bywa też i tak, że dwa różne obrazy zlewają się ściśle z sobą, tworząc obraz kontaminowany i potwierdzony odpowiednią werbalizacją ( "to są człowiekoptaki"). Kontaminacja uważana jest często za wyraz zaburzeń poznawczych, natomiast akceptacja wieloznaczności plam i odpowiedni dystans do zawartych w nich sprzeczności łączą się, w mojej opinii, z dojrzałością psychiczną.

3. Obrazkowa kultura zachodniego świata nie sprzyja zrozumieniu, że percepcja wzrokowa jest zjawiskiem złożonym 
Na fakt, że widzenie wydaje się czymś prostym i naturalnym wskazuje Tom Mitchell, zaraz jednak dodaje, że stwierdzenie to odnosi się jedynie do najbardziej podstawowych umiejętności wzrokowych [10]. Należy tu jednak zaznaczyć, że odczucie oczywistości percepcji wzrokowej jest charakterystyczne głównie dla kultury świata zachodniego, a doświadczenia Jana Deręgowskiego, profesora uniwersytetu w Aberdeen, sugerują, że nawet bardzo podstawowe zdolności wizualne mogą stanowić problem, zwłaszcza w kulturach nieobeznanych z obrazami jako wytworami kultury. Badania tego profesora pokazały, że przedstawiciele społeczeństw spoza kultury zachodniej nierzadko, gdy pokazywano im rysunki znanych przedmiotów lub fotografie członków ich rodzin, odczuwali żywiołowy lęk, byli zdezorientowani, nie potrafili odróżnić rysunku od podłoża, na którym był on wykonany, a także nie umieli wskazać, co na obrazie jest figurą, a co tłem [11]. Wspominany już tutaj Arnheim uznaje zdolność do rozróżniania figury i tła za fundamentalną, bardziej podstawową niż percepcja kształtu. Dla członków kultur „przedobrazkowych” trudnością okazało się też dokonywanie syntezy poszczególnych elementów obrazu w jedną całość.

Można zauważyć, że niektóre sposoby reagowania osób badanych testem Rorschacha, a należących do kultury zachodniej, bywają podobne do reakcji osób z kultur nieobeznanych z obrazami. Można powiedzieć, że następuje tu regresja w odbiorze obrazów, ale jest ona sprowokowana wieloznacznością bodźców. Jednym z przykładów takiego reagowania może być tzw. „percepcja indukcyjna" [8]. Percepcja indukcyjna polega na tym, że osoba patrząca na plamę nie widzi jakiegoś przedmiotu w całości, lecz koncentruje się na poszczególnych jego elementach, wymienia je i stopniowo, z pewnym opóźnieniem, łączy ze sobą, by dopiero na końcu tego procesu uświadomić sobie, że utworzyła pewną całość, którą teraz potrafi zidentyfikować i nazwać. Np. badany mówi: „o tu są stopy, tu nogi, a tu ręce, o, a i głowa - to jest jakaś postać".

Deręgowski zaobserwował, że niektórzy członkowie kultur nieobrazkowych przyjmują jedną $\mathrm{z}$ dwu przeciwstawnych postaw: albo biorą obrazy za rzeczywiste przedmioty lub przeciwnie, nie potrafią przypisać im jakiegokolwiek znaczenia [11]. Skłonna jestem sądzić, że oba te typy reagowania mogą świadczyć o trudnościach w uchwyceniu reprezentacyjnej, symbolicznej funkcji obrazu. Podobne do tych zachowań są postawy przyjmowane podczas interpretacji plam w teście Rorschacha, które opisał Dawid Rapaport [12]. Pierwsza z nich to postawa utraty dystansu do plam. Mamy z nią do czynienia wówczas, gdy badany traktuje plamy jako posiadające jedno konkretne znaczenie, które należy odgadnąć. 0 takich przypadkach pisał też
Paluchowski [13], a moja praktyka potwierdza dość częste występowanie tej postawy.

W mniej wyraźnej postaci może ona wyrażać się w zakłopotaniu przy podawaniu kolejnej interpretacji danej plamy lub jej części albo w komentarzach typu: „to mogłaby być gałąź, gdyby to nie była noga człowieka". Druga postawa to nadmierny dystans do plam, z którym mamy do czynienia, gdy badany nie liczy się w dostatecznym stopniu z cechami plamy i poddaje się potokowi skojarzeń, które nie są zakotwiczone w prezentowanym bodźcu. Obie te postawy Rapaport uważa za coś naturalnego, co ma prawo pojawiać się w każdym badaniu, badane osoby powinny jednak być w stanie postawy te kontrolować i mieć świadomość, że mają do czynienia ze znakami, które z jednej strony zezwalają na pewien stopień swobody, ale z drugiej wy magają „realizmu” i „poczucia rzeczywistości”.

Mimo że spostrzeganie obrazów i interpretowanie plam może sprawiać większe lub mniejsze trudności, percepcja wzrokowa wydaje się czynnością łatwą $i$ oczywistą, choć wcale nie musi taką być, jak już o tym wspominałam. Do takich odczuć może przyczyniać się współczesna kultura, która przepełniona jest obrazami. Można powiedzieć, że cierpimy na ich nadmiar, a co więcej, że obrazy coraz częściej wypierają słowa. Gilbert Durand mówi metaforycznie, że „dławimy się obrazami”[14].

4. Według Rorschacha i współczesnego mu Roberta Vischera ujrzenie czegoś w plamach dokonuje się poprzez mechanizm projekcji i introjekcji

Powtórzmy: Rorschach stworzył plamy w celu eksperymentalnego badania szeroko rozumianego doświadczenia percepcyjnego człowieka. Za swoim nauczycielem Eugenem Bleulerem przyjmował, że percepcja to nie bierne przypatrywanie się czy odzwierciedlanie świata, lecz aktywna partycypacja człowieka w świecie. Percepcja w tym ujęciu polega na dostosowywaniu danych sensorycznych do posiadanych już $w$ umyśle śladów pamięciowych (engramów). Dostosowywanie to obejmuje całą istotę człowieka, jego poznanie, afekt i fizyczność (cielesność). Badacze nie dotarli do informacji, które świadczyłyby o tym, że Rorschach znał poglądy współczesnego mu Vischera, ale pojmowanie percepcji przez obu tych myślicieli jest bardzo podobne. Vischer, powołując się na Karola Alberta Scherera, uważał, że percepcja to rzutowanie mentalno - sensorycznego ego do wnętrza przedmiotu (projekcja). Rzutowanie to bywa tak intensywne, że można metaforycznie powiedzieć za Vischerem, że podmiot „wchodzi” w kontury przedmiotu, tak jakby „ubierał się” w skrojone dla siebie ubranie. Rzutowanie to można nazwać swoistą „empatią". Rorschach mówił o wczuwaniu się, które jest szczególnie intensywne przy percepcji ruchu. Według Vischera empatia nie jest zjawiskiem jednostronnym. Przedmiot 
funkcjonuje jak płyta rezonansowa - odbija to, co zachodzi między nim a podmiotem i w ten sposób, poprzez mechanizm introjekcji, oddziaływuje na podmiot, zmienia go $[2,5,15]$.

\section{Teoria znaku Charlesa Sandersa Peirce'a, a znakowy charakter plam atramentowych}

Jak sugerowałam we Wstępie, plamy atramentowe to swoiste znaki i taki pogląd zdaje się być ogólnie akceptowany $\mathrm{w}$ fachowej literaturze psychologicznej. Nie spotkałam jednak żadnych szerszych omówień tego zagadnienia, a wydaje się, że sięgnięcie po semiotykę może w przypadku Rorschacha dać ciekawe rezultaty. W niniejszym artykule odwołam się do teorii Peirce'a, starając się w jej świetle scharakteryzować specyfikę plam Rorschacha.

5. Znak należy do porządku ontycznego

Semiotyka wyodrębniła się $\mathrm{z}$ jednej strony $\mathrm{z}$ lingwistyki i wiedzy o języku, a z drugiej strony z filozofii logiki. Jako najbardziej znaczącego przedstawiciela językoznawstwa należy wymienić Ferdinanda de Saussure'a, a jako najwybitniejszego filozofa uznanego za ojca współczesnej semiologii Peirce’a. De Saussure pojmował język jako uniwersalny i abstrakcyjny system o wewnętrznej organizacji (stąd uważa się go za ojca strukturalizmu); twierdził on, że znak to połączenie pojęcia (signifé) i dźwięku (signifiant). Oba te elementy ściśle do siebie przylegają i choć tkwią w umyśle (pojęcie i ślad bodźca) są czystą abstrakcją, należą do ponadindywidualnego systemu językowego, istniejącego w świadomości społecznej - la langue. Znak jest u niego wytworem idealnego umysłu ( a więc psychologizm koncepcji Saussure'a jest pozorny), nie ma w niej miejsca ani dla przedmiotu (świata), ani dla podmiotu [16-18]. Tej dualistycznej teorii znaku Saussure'a przeciwstawia się triadyczna koncepcja znaku Peirce’a. Według tego drugiego, znak to relacja łącząca trzy elementy. Pierwszy z nich to nośnik znaku, jego materialne podłoże. Drugi element to przedmiot znaku, czyli to, na co znak wskazuje. Trzeci element znaku to jego znaczenie, czyli interpretant, element kluczowy znaku. Interpretant pośredniczy między środkiem przekazu (nośnikiem), a przedmiotem, odnosi pierwsze do drugiego, ale ważne jest to, że zawsze odnosi się do niego tylko pod jakimś względem. Nigdy w znaku nie chodzi o prostą substytucję: znak nigdy nie zastępuje przedmiotu - zawsze chodzi tu o reprezentację, czyli o odnoszenie się do przedmiotu jedynie w jakimś aspekcie. Dlatego Hanna Buczyńska-Garewicz pisze, że znak mówi o przedmiocie zarówno mniej, jak i więcej: mniej, bo nie obejmuje całości wiedzy o przedmiocie, a więcej, bo - koncentrując się na wybranych aspektach przedmiotu - niesie z sobą jakąś nową wiedzę. Z tej wybiórczej reprezentacji przedmiotu wynika, że nie można rozumieć go jako rzeczy istniejącej fizycznie. Przedmiot jako rzecz istniejąca fizycznie nie należy do znaku, nie jest jego elementem; przedmiot nie jest dla znaku konstytutywny. Podobne jest $\mathrm{z}$ interpretantem. Interpretant jest istotnym elementem znaku, nie można jednak mylić go $\mathrm{z}$ interpretatorem, użytkownikiem znaku, odbiorcą znaku, podmiotem; podmiot, podobnie jak i przedmiot fizyczny, pozostaje na zewnątrz znaku. Znak jako byt niezależny od podmiotu i przedmiotu ma charakter ontyczny, istnieje niezależnie od tego, czy jest interpretowany czy nie. Interpretacja jest relacją występującą pomiędzy znakami. „Interpretant znaku jest realizacją jego znaczenia, jest wydobyciem tego znaczenia ze stanu czystej możliwości, jest jego ujawnieniem. Znaczenie znaku ukazuje się przez inny znak." [19].

Interpretacja stanowi najgłębszą naturę myśli, ale myśl nie jest aktem świadomości, lecz faktem ontycznym, należy do świata obiektywnego. Peirce wprowadza pojęcie interpretatora zewnętrznego i pojęcie przedmiotu zewnętrznego. Przedmiot zewnętrzny należy rozumieć jako wszystko to, co należy do realnie istniejącego świata. Mimo tego, że znak ma charakter ponadindywidualny i należy do sfery idealnej, to jednak jest ukierunkowany na przedmiot zewnętrzny i to ukierunkowanie jest dla znaku konstytutywne. Koncepcja znaku u Peirce'a cechuje się więc realizmem poznawczym ( a nie immanentyzmem epistemologicznym). Myśl, choć należy do porządku idealnego, ontycznego, jest nadbudowana nad przedmiotem, liczy się $\mathrm{z}$ realnym światem, a znaczenie znaku odpowiada faktycznemu ukształtowaniu przedmiotu. Jak pisze Buczyńska-Garewicz, Peirce przyjmuje jedność myśli i świata, polegającą na powszechnym występowaniu w obu tych sferach relacji triadycznej. Podobnie rzecz ma się $\mathrm{z}$ interpretatorem zewnętrznym, a więc $\mathrm{z}$ odbiorcą znaku, podmiotem. Mimo że pozostaje on na zewnątrz znaku, to jednak akty myślowe, procesy semiozy dokonujące się w konkretnym umyśle mają taką samą strukturę, jak proces semiozy niementalnej, ontycznej. Semiozę (ogół aktów znakowych) ontyczną określa się mianem potencjalnej, zaś semiozę zachodzącą w konkretnym umyśle określa się mianem aktualnej. Ta ostatnia podąża za ontycznym porządkiem świata. Możemy powiedzieć, że semioza aktualna podąża za semiozą potencjalną i to ta ostatnia jest uprzednia, zarówno pod względem chronologii, jak i pod względem ważności [20].

6. Znak domaga się, by być interpretowanym w innym znaku

Można mieć wrażenie, że Peirce, wprowadzając do znaku interpretanta, wprowadził tym samym element przestrzenności. W moim odczuciu można powiedzieć, że ujęcie znaku jako „płaskiego” połączenia signife' i signifiant zostało „rozszczelnione” poprzez relację 
odnoszącą nośnik znaku do przedmiotu znaku dzięki trzeciemu elementowi, jakim jest interpretant. Podobnie Buczyńska-Garewicz stwierdza za Peirce'em: " Na skutek tego, że każdy znak określa swego interpretanta, który sam też jest znakiem, mamy nakładanie się znaku na znak" [19]. Co więcej, Peirce wprowadził też element dynamiki, również dzięki interpretantowi. Tak jak przedmiot nie jest dostępny bezpośrednio, a jedynie pośrednio poprzez interpretanta, tak sam interpretant może być poznany jedynie pośrednio, poprzez inny znak, a tym innym znakiem jest właśnie interpretant. Interpretant pełni więc podwójną rolę. Jest istotnym, wewnętrznym elementem znaku, ale jednocześnie jest też innym znakiem, zewnętrzną w stosunku do tego znaku jego interpretacją. Interpretant nie tylko jest znaczeniem znaku, ale jednocześnie jest tym, co wskazuje na środek przekazu (nośnik) z intencją, by był on zinterpretowany przez inny znak, a tym innym znakiem staje się on sam. Można to sobie wyobrazić jako akt podwojenia się interpretanta: jest on znaczeniem znaku i innym znakiem. Można powiedzieć metaforycznie, że interpretant pozostając znaczeniem „macierzystego” znaku, „rodzi” znak następny. A więc znaki mają swoją dynamikę. Znaczenie znaku - mimo tego, że jest jego istotą - nie jest całkowicie wewnętrznym elementem triady, nie jest $w$ niej „zamknięte”. Znów, posługując się metaforą, można powiedzieć, że znaczenie znaku „wylewa się” w jakiś sposób ze znaku, „wyziera” z triady znakowej.

7. Znak istnieje tylko w systemie innych znaków, jest ogniwem w procesie nieustannej semiozy

Aktywność interpretanta sprawia, że każdy znak wymaga istnienia innego, uprzedniego znaku, by być jego interpretantem i też wymaga znaku następnego, tak by ten z kolei interpretował jego znaczenie. Konieczność ciągłej interpretacji wynika z fragmentaryczności, z tego, że znak ujmuje przedmiot tylko pod jakimś względem, dotyczy jedynie jego wybranego aspektu. BuczyńskaGarewicz pisze, że interpretant nie tylko spaja nośnik znaku z jego przedmiotem, ale także spaja znak z innymi znakami, i to sprawia, że w systemie znaków działa jakby élan vital świata znaków, która spaja go i rozwija [16,19]. Nie jest możliwe, by znak istniał poza systemem znaków. Znaki mają swoją "interpretowalność”, „przekładalność” i nie są w stanie zaniechać tej swojej aktywności, muszą generować następne znaki. Podmiot, podążając za potencjalnymi aktami interpretacyjnymi, jest niejako zmuszony do uczestniczenia w procesie nieustannej semiozy; znów, posługując się metaforą, powiem, że znaki go „pociągają", , uwodzą"

8. Przedmiot domaga się interpretacji, znaczenie świata objawia się podmiotowi

Jak już było wspominane, znak (myśl) w ujęciu Peirce'a należy do sfery idealnej, ale jest on ukierunkowany na przedmiot zewnętrzny i to ukierunkowanie jest dla znaku konstytutywne. Można więc przyjąć, że myśl, znak, są czymś wtórnym, nadbudowanym nad bytem przedmiotowym i nie wytwarzają go, lecz są - pomimo swej autonomii - podporządkowane światu. Podobnie jak interpretant wewnętrzny, interpretant zewnętrzny nie wytwarza znaczenia, lecz znaczenie to rozpoznaje; jest sposobem, jak pisze Buczyńska-Garewicz, przejawiania się zrozumienia znaku $[16,19,21]$. Sytuację tę znamy z własnego doświadczania znaczenia: odczuwamy, że znaczenie znaków to nie swobodny wytwór naszej jaźni, lecz coś, co jest nam dane, oferowane naszej jaźni. Podobnie jak znak domaga się interpretacji, tak i przedmiot żądny jest tego, by uzyskać swe znaczenie, znaleźć swą sygnifikację. Ciekawe dla psychologów, posługujących się testem Rorschacha, jest spostrzeżenie Wojciecha Kalagi, ilustrujące dążenie przedmiotu, by stać się znakiem. Autor ten przywołuje sytuację lania wosku, która jest przecież niemal tożsama $\mathrm{z}$ interpretowaniem plam : „...w tradycyjnej zabawie tzw. lania wosku wyłaniający się kształt domaga się - zgodnie z zasadami tej zabawy - przyznania mu znaczenia" [20].

9. Niektóre charakterystyki przypisywane znakom przez Peirce'a są widoczne w sytuacji badania testem Rorschacha

Znaczenia ukryte w plamach można traktować jako niekończący się zbiór różnych spostrzeżeń, które domagają się interpretacji. Takiego ujęcia doświadcza psycholog stosujący ten test. Lata posługiwania się nim przynoszą coraz więcej niemal identycznych wypowiedzi, ale nigdy nie jest tak, by nie pojawiały się, choćby z rzadka, nowe, oryginalne interpretacje. Doświadczenie tej sytuacji łączy się z zaskoczeniem i zdumieniem: jak to może być, że tak bardzo „wyeksploatowane” bodźce zdolne są ukazać swoją jeszcze jedną, nieznaną dotąd stronę. Można powiedzieć, że Rorschach - jakimś trafem, jakby niechcący - wręcz zilustrował opisane przez Peirce'a funkcjonowanie znaków.

Po pierwsze, widać jak bardzo kolejne znaczenia wydobywane ze znaku (plamy) są niewystarczające, nie oddają pełnego bogactwa znaczeń w nim zawartych. Po wtóre, najczęściej reakcją na sytuację interpretowania plam jest ożywienie, zaangażowanie badanej osoby. Można mieć wrażenie, że poddaje się ona presji znaków, by być interpretowanymi, że jest zaintrygowana jakąś przeczuwaną, tkwiącą w plamach tajemnicą. Czasem zdarza się, że potencjalny badany odmawia wykonania testu albo manifestuje negatywne emocje, najczęściej w formie krytyki testu. W mojej ocenie zachowania takie najczęściej są mechanizmem obronnym, stosowanym w celu uniknięcia sytuacji niepewności lub też wynikają $\mathrm{z}$ innej sytuacji badanego, zewnętrznej $\mathrm{w}$ stosunku do plam i nie wynikającej z ich natury i nieistotnej dla 
procesu semiozy. Interpretująca plamy osoba najczęściej ma wrażenie, że nie tworzy, ale „odkrywa” zawarte w nich obrazy. To ostatnie doświadczenie może na przedświadomym poziomie dawać poczucie uczestnictwa w ontycznym porządku świata.

\section{Fenomenologia percepcji a interpretacja plam}

Głównym zainteresowaniem Rorschacha, jak już było wspominane, była percepcja, a szczególnie percepcja ruchu. Akavia podaje, że zauważenie dynamiki w statycznej plamie według Rorschacha nie było iluzją, lecz wyrazem subiektywnego doświadczenia. Wskazuje ona na podobieństwo poglądów szwajcarskiego psychiatry do poglądów współczesnego mu fenomenologa Edmunda Husserla. Dla tego ostatniego umysł ludzki to "intencjonalna siła" ujmująca dane zmysłowe w subiektywnym, źródłowym doświadczeniu sensu. Co więcej, $\mathrm{w}$ doświadczeniu tym fundamentalną rolę odgrywa kinestezja, stanowiąca jądro subiektywności i warunek kształtowania się selfu. Podobnie Rorschach mówi o „wczuwaniu się” przy spostrzeganiu ruchu, a więc o zaangażowaniu ciała $\mathrm{w}$ tej percepcji. I w fenomenologii Husserla ciało odgrywa istotną rolę $w$ postrzeganiu zmysłowym. Filozof ten mówi o ciele wizualnym, dotykowym oraz o ciele woli i kinestezji; to ostatnie stanowi „centrum” podmiotu i umożliwia pojawienie się intersubiektywności i obiektywizacji poznania. Należy zaznaczyć, że Husserl daleki był od psychologizmu, a jego rozważania dotyczą porządku transcendentalnego [19, 22]. Po analizie dostępnych żródeł Akavia skłania się do przyjęcia, że Rorschach nie znał pism Husserla. Helen Malmgren w artykule z 2000 roku [23] wspomina innego fenomenologa, a mianowicie Maurice'a Merleau-Ponty'ego, którego pierwsza książka La structure du comportment ukazała się ponad dwadzieścia lat po śmierci Rorschacha. Najdobitniej poglądy tego francuskiego filozofa wyrażone zostały w pracy Phenomenologie de la perception. Można odnieść wrażenie, że jeśli Rorschach kontynuowałby swoje rozmyślania na temat percepcji, musiałby pójść podobną drogą co Merleau-Ponty, a nawet, że to twórcę plam atramentowych można by uznać za jednego $\mathrm{z}$ niezauważonych i zapomnianych prekursorów pojęcia „ucieleśnionej percepcji” (obok Vischera i Scherera). Podobieństwo myśli Rorschacha i Merleau-Ponty'go wydaje się tak znaczące, że brak gruntownej analizy tego zagadnienia jest zaskakujący.

10. Według Merleau-Ponty’ego projekcja i introjekcja są istotnymi mechanizmami zaangażowanymi w procesie percepcji

Główna teza Merleau-Ponty'ego mówi, że spostrzeżenie wymaga fuzji podmiotu i przedmiotu, że jest spełnieniem programów motorycznych ciała rzutowanych na spostrzegane przedmioty. Projekty motoryczne obejmują część środowiska - mamy więc do czynienia z projekcją. Z kolei ta „zajęta” część otoczenia zostaje włączona w schemat ciała, działa tu więc także mechanizm introjekcji. Organizm postrzegający i jego środowisko wzajemnie na siebie zachodzą [24, 25]. Widzimy więc, że i dla Rorschacha, i dla Merleau-Ponty'ego percepcja jest możliwa dzięki aktywności podmiotu, dzięki jego wychodzeniu na zewnątrz ku światu i wchłanianiu świata, odpowiadaniu na tego świata apel, by go przyswoić. Powiedzmy, znów posługując się metaforą: podmiot łączy się ze światem tak, jak organizm łączy się ze swym pożywieniem, zamieniając je w swoją własną tkankę. Jacek Migasiński pisze o percepcji według Merleau-Ponty’ego: „Percepcja jest wobec tego spełnieniem na zewnątrz moich sensotwórczych potencji, jest jakby zjednoczeniem mojego ciała z rzeczami, swoistą "komunią z nimi" [25]. Podobną „zachłanność” w zachwycie nad wizualną wspaniałością świata spotykamy u Rorschacha. Zauważa ją Searls [5], cytując ulubiony poemat Rorschacha autorstwa Gottfrieda Kellera. Ostatnie dwa wersy tego poematu (cytuję je za Searlsem, w tłumaczeniu na angielski) brzmią:

Drink in, oh eyes, all your lashes can hold

of the golden abundance of the world.

och oczy! Spijajcie aż do dna samego

Całą ta obfitość świata wspaniałego!

[tłum. własne autorki]

11. Ciało i percepcja rozpatrywane są jako byty transcendentalne

Centralnym tematem fenomenologii MerleauPonty'ego jest ciało. To ono jest punktem, z którego człowiek patrzy na świat i to dzięki ciału możliwe jest ludzkie doświadczanie świata. Na doświadczeniu tym zasadza się cała filozofia francuskiego fenomenologa. Ukazuje ono świat nie zniekształcony żadną refleksją. „Wszystko, co wiem o świecie, nawet w sposób naukowy, wiem dzięki swojemu widzeniu i dzięki doświadczaniu świata, bez którego symbole nauki nie miałyby żadnego znaczenia" [24]. Czysty opis tego doświadczenia to powrót do rzeczy samych w sobie, sprzed poznania, z pominięciem dorobku nauki, która ujmuje świat w sposób abstrakcyjny, wykorzystując znaki.

Jak zauważa Migasiński [25], Merleau-Ponty, zanim objął katedrę filozofii w College de France, kierował katedrą psychologii i pedagogiki na Sorbonie. Stąd w tekstach francuskiego filozofa wiele stron poświęconych jest psychologicznym, szczegółowym analizom percepcji i opisom eksperymentów psychologicznych z uwzględnieniem psychopatologii. Merleau-Ponty unika jednak psychologizmu, dąży do tego co uniwersalne, a ciału i percepcji nadaje status ontyczny. Świat według niego jest dokładnie tym, co podmiot sobie 
przedstawia, ale podmiot czyni to jako równoprawny uczestnik jednego, niepodzielnego świata. Mimo że dla każdego podmiotu doświadczenie świata jest „jego” doświadczeniem, to jednocześnie od razu charakteryzuje się pewną anonimowością, niesie za sobą struktury ogólne, a kontakt z przedmiotem nie jest narzędziem, ale rdzennym elementem świadomości, tożsamym z doświadczeniem innych ludzi, świadomość jednostki niczym nie różni się od „innej” świadomości, ponieważ wszyscy jesteśmy bezpośrednio obecni wobec świata. W każdym podmiocie postrzeganie świata jest dziełem nie jednostki, ale dziełem świadomości przedosobowych, co sprawia, że intersubiektywność jest fundamentem relacji społecznych. „Percepcja jako związek z bytem tworzy ontologiczne ramy ukonstytuowania się rzeczywistości świata jeszcze przed jakąkolwiek myślą teoretyczną " [25].

12. Świat jawi się przedmiotowi i domaga zaistnienia w jego świadomości

W przedmowie do „Fenomenologii percepcji” Merleau-Ponty pisze: "Rzeczywistość jest tkanką trwałą, nie czeka na nasze sądy..." [24]. Podmiot nie konstruuje świata, przeciwnie, to on jest „wydany światu”. Świat jest „naturalnym” środowiskiem i polem wszystkich myśli i wszystkich moich wyraźnych postrzeżeń i to świat wyprzedza wszelką analizę. Francuski fenomenolog czyni tu zastrzeżenie: świat nie jest tym, co myślimy, ale tym, co spostrzegamy [24]. Rzeczywistość ma status ontyczny, a podmiot doświadcza jej, przeżywa świat.

Podmiot przeżywa świat dzięki ciału, które, jak to już było powiedziane, również należy do porządku ontycznego. To ciało jest naszym ogólnym sposobem komunikowania się ze światem i pozwala na pewien stopień posiadania go; piszę „pewien stopień ”, ponieważ świat według Merleau-Ponty'ego jest w swej naturze niewyczerpywalny [24]. Ciało wyposażone jest w pewne zdolności motoryczne, pewne moce, które nie są jednak prostą mocą fizyczną, lecz intencjonalnością, ukierunkowaniem na świat. Podmiot zdolny jest rzutować projekty motoryczne na zewnątrz, w rezultacie czego świat nabiera nowych sensów. To dzięki ciału podmiot staje się bytem intencjonalnym i aktywnym, a w jego jaźni ujawniają się nowe znaczenia i sensy. To ciało penetruje otoczenie i jednoczy je z rzeczami. Percepcja zawsze jest „poznaniem ucieleśnionym”, ujmuje świat poprzez przylgnięcie do rzeczy, jest czymś więcej niż poznaniem, jest naszą „przynależnością” do rzeczy, a wiedza pojęciowa zawsze jest zakorzeniona w tej pierwszej, nierefleksyjnej, cielesnej, „wiedzy” o świecie. Byt zawsze ujmowany jest w jakiejś cieleśnie uwarunkowanej perspektywie. Nie można nie zauważyć, że ta otwartość na świat, wychodzenie w świat to jednocześnie ekspresja podmiotu, ucieleśnienie się nowych znaczeń w świecie.
Według Merleau-Ponty’ego źródło świadomości to poczucie „mogę”, a nie „myślę”. „Mogę” wyraża się w rzutowaniu programów motorycznych, w przyjęciu aktywnej postawy wobec świata, w ukierunkowaniu się na sferę możliwych percepcji i możliwych działań. Percepcja i ekspresja ustala relacje łączące podmiot ze światem. Możemy więc powiedzieć, że podmiot komunikuje się z otoczeniem, odpowiada na apel ze strony świata, a świat domaga się tego, by zaistnieć w jaźni podmiotu, by być opisanym i przeżytym.

13. Przedmiot zawsze jest ujmowany w kontekście innych przedmiotów a percepcja jest procesem nieustannym

Według Merleu-Ponty’ego percepcja, choć jest poznaniem bezpośrednim, nie-pojęciowym, nigdy nie ujmuje całej prawdy o przedmiocie. W pierwszej fazie patrzenia wzrok ujmuje całość rozciągającego się przed oczyma widoku, a następnie spojrzenie pada na wybrany fragment pola wzrokowego, na wybraną rzecz. Wybrany obiekt ożywa, rozwija się jakby, podczas gdy pozostałe przedmioty wycofują się, tworząc tło. Patrzeć na jakiś przedmiot to umieszczać się w nim i z jego pozycji patrzeć na inne przedmioty. Inne przedmioty widzę więc tylko tak, jak na to pozwala wybrany przeze mnie uprzednio przedmiot, i tylko w taki sposób, w jaki on „widzi” te przedmioty. Ale pozostałe przedmioty także stają się moimi siedzibami i też z ich pozycji patrzę na rzecz, która jako pierwsza była moim zainteresowaniem. W ten sposób każdy przedmiot w moim polu widzenia staje się zwierciadłem pozostałych przedmiotów. Wybrany obiekt widzę z wielu stron, na co pozwala mi moja własna pozycja i pozycja innych przedmiotów. Można wiec powiedzieć, że przedmiot może być spostrzeżony dzięki temu, że umieszczony jest wśród innych przedmiotów, że jest elementem całego systemu rzeczy, częścią świata rzeczy. Ale moje spojrzenie nigdy nie jest w stanie ująć daną rzecz pod każdym możliwym kątem. Gdy pojawia się nowa, lecz niekompletna wiedza, podmiot motywowany jest do następnych działań, by choć w jakimś stopniu wiedzę tę dopełnić, by choć w części zniwelować jej fragmentaryczność. Mimo tych wysiłków przedmiot nigdy nie pojawi się w świadomości podmiotu w całej swej prawdzie. Przedmiot, który pojawiłby się w całej swej kompletności byłby przedmiotem doskonałym. MerleauPonty opisuje go w następujący sposób: „Doskonały przedmiot jest przejrzysty, ze wszech stron przeniknięty przez aktualną nieskończoność spojrzeń, które spotykają się w jego głębi i niczego nie zostawiają w ukryciu" [24]. Świat jawi się podmiotowi jako świat niekompletny, „ułamkowy” i ta fragmentaryczność świata staje się apelem o dalsze wysiłki, a podmiot odpowiada na to wołanie. „Widzieć to wkraczać w uniwersum bytów, które się ukazują, a nie mogłyby się ukazywać, gdyby nie mogły 
się ukrywać jedne za drugimi albo za mną" [24].

14. Merleau-Ponty'ego fenomenologia percepcji stanowi niezamierzone, ale uderzająco konsekwentne dopełnienie i rozwinięcie poglądów Rorschacha

Zarówno dla Rorschacha, jak i dla Merleau-Ponty'ego percepcja to subiektywne doświadczenie możliwe dzięki aktywności podmiotu i realizujące się poprzez mechanizm projekcji i introjekcji. Rorschach mówi o interioryzacji spostrzeganego ruchu (introjekcja) i rzutowaniu go na statyczną plamę (projekcja). Merleau-Ponty twierdzi, że percepcja możliwa jest dzięki zdolności „ujmowania” świata w projektach motorycznych: podmiot „umieszcza się” w przedmiocie, „zakorzenia się” w nim [24], a część środowiska zawłaszczona przez działanie projektów motorycznych zostaje włączona w schemat ciała (introjekcja). Dla obu tych myślicieli podmiot, wchłaniając świat, aktywnie go doświadczając wyraża siebie w swej subiektywności; percepcja łączy się z ekspresją, a percepcja jest przeżyciem. Migasiński [25] wskazuje, iż dla francuskiego fenomenologa to dzięki ciału tworzy się jedność przeżywanego świata i podmiotu, jedność, którą opatruje on terminem „obecność”. Akavia określa Rorschacha koncepcję percepcji jako koncepcję „percepcji ucieleśnionej”, a więc posługuje się terminem, który wydaje się być „zarezerwowany” dla Merleau-Ponty’ego [2]. Autorka ta podkreśla także znaczenie pojęcia subiektywności w Rorschacha rozumieniu percepcji: subiektywność jest dla niego zindywidualizowaną, naznaczoną podmiotową, osobistą, emocjonalną i ucieleśnioną historią [2].

Obu omawianych tu myślicieli łączy także fascynacja ruchem, który jest ekspresją doświadczaną dzięki ciału. W literaturze wielokrotnie wspominany jest sen Rorschacha, będący reminiscencją pierwszego udziału autora plam w sekcji. W śnie tym doznał on wyrazistego i dojmującego, niemal fizycznego wrażenia, że jego własny mózg jest krojony w plastry. Ciekawsza jednak niż sam sen jest jego interpretacja dokonana przez Rorschacha, a mianowicie uświadomił on sobie jasno, że wzrokowa percepcja może ulec przekształceniu w doznanie cielesne [5].

Spostrzeganie ruchu w statycznej plamie było dla Rorschacha najciekawsze. Analizował on wypowiedzi determinowane kształtem plam, ich kolorem czy widocznym na nich światłocieniem, lecz uważał, że wypowiedzi mówiące o ruchu to ekspresja najbardziej osobistych, najgłębszych przeżyć badanej osoby i to te wypowiedzi ujawniają istotę selfu. Merleau-Ponty, rozpatrując zagadnienie przestrzenności ciała i motorykę, pisze: „Ciało własne jest źródłem wszystkich innych przestrzeni, samym ruchem ekspresji, tym co rzutuje znaczenia na zewnątrz, udzielając im miejsca, tym, co sprawia, że zaczynają one istnieć jako rzeczy, pod naszymi rękami, przed naszymi oczami" [24]. Ciało dla tego fenomenologa jest "przestrzenią ekspresyjną” i ogólnym sposobem poznania świata. Znaczenie ruchu podkreśla jego cytat z Alberta S. F. Grunbauma: „Motoryczność jest sferą pierwotną, w której rodzi się sens wszystkich znaczeń (der Sinn aller Signifikationen) w obszarze przestrzeni podstawowej" [24]. Dzięki motoryczności człowiek uświadamia sobie własne ciało i jego miejsce w świecie, możemy więc powiedzieć, że na tej kanwie możliwe jest doświadczenie samego siebie, a więc kształtowanie się selfu.

Wymienionych wyżej podobieństw w poglądach obu omawianych tu autorów nie unieważnia, jak myślę, różnica w ich pojmowaniu natury podmiotu i poznania. Rorschach zapewne traktował percepcję jako zjawisko psychologiczne, a ogólniejsze problemy ujęte filozoficznie prawdopodobnie nie były dla niego tak istotne. Dla Merleau-Ponty'ego natomiast, tak jak już wspominałam, podmiot był anonimowy, „transcendentalny”; filozof przypisywał mu charakter uniwersalny. Percepcja zaś, jako związek $\mathrm{z}$ bytem, tworzy ontologiczne ramy ukonstytuowania się rzeczywistości świata. W porównaniu obu myślicieli najważniejsze jednak wydaje się to, że obaj piszą o percepcji jako o aktywnej i pełnej ekspresji penetracji świata, o ścisłym kontakcie podmiotu ze światem i o wzajemnym ich oddziaływaniu na siebie. Łączy ich także znacząca rola ciała w percepcji. Dla Merleau-Ponty'ego percepcja stanowi podstawę poznawania świata, w niej zakotwiczona jest wszelka wiedza, nawet ta zakodowana w znakach. Rorschach, czyniąc percepcję swoim głównym przedmiotem zainteresowania, zdawałby się podzielać to stanowisko.

\section{Rorschach i Merleau-Ponty a Peirce, co łączy ich a co dzieli}

15. Mimo że na pierwszy rzut okiem Peirce'a teoria znaku jest zupełnie różna od koncepcji poznania wypracowanej przez Merleau-Ponty'ego, to jednak podobieństwa między poglądami amerykańskiego semiotyka i francuskiego fenomenologa istnieją i można odnieść je również do myśli Rorschacha

Peirce'a teoria znaku skoncentrowana jest na znaczeniu, podczas gdy Merleau-Ponty i Rorschach zainteresowani byli percepcją rozumianą jako formą przeżycia, doświadczania świata.

W rozważaniach, jakie tu przeprowadzam, Peirce zajmuje miejsce osobne: skoncentrowany na znakach uważał, że wyłącznie poznanie pośrednie jest poznaniem wartościowym, mimo że zawsze ma ono charakter fragmentaryczny, niepełny. Merleau-Ponty pojmował percepcję w sposób oryginalny i odmawiał jej zdolności do 
uchwycenia całej prawdy o przedmiocie.

Widzimy więc już pierwsze podobieństwo, łączące Peirce'a i Merleau-Ponty'ego: ocena możliwości poznawczych człowieka jest podobna u obu tych filozofów. Co więcej, niepełność poznania jest motywem do ponawiania aktów poznawczych. U Peirce’a znak domaga się interpretacji w innym znaku. Myśl dąży do prawdy w niekończącym się procesie semiozy, a podmiot podąża za obiektywnym, ontycznym porządkiem interpretacji, poddaje się presji znaków. U Merleau-Ponty'ego podobnie, percepcja nie ujmuje całego przedmiotu, nieskończona liczba możliwych kierunków, z jakich patrzymy na dany przedmiot sprawia, że poznanie musi realizować się stopniowo, w kolejnych aktach percepcji, a ujęcie całej prawdy nigdy nie ma szans na zrealizowanie.

Tutaj należy przyznać, że w teorii Peirce’a końcowym celem poznania jest cała prawda o przedmiocie, podczas gdy francuski fenomenolog akceptuje niepełność poznania.

Następne podobieństwo myśli obu omawianych tu filozofów kryje się w ich odrzuceniu psychologizmu i w ujęciu poznania jako należącego do ontycznej strony świata (Peirce) lub do sfery uniwersalnej, transcendentnej w stosunku do poznającego podmiotu (Merleau-Ponty - ontyczny poziom poznania jest u tego filozofa mniej zdecydowanie podkreślany). Osobiście biorę pod uwage możliwość, że podmiot zdaje sobie sprawę, choćby na przedświadomym poziomie, że choć kontakt ze światem jest jego osobistym doświadczeniem, jednocześnie jest doświadczeniem tożsamym $\mathrm{z}$ doświadczeniem transcendentalnym, intersubiektywnym, należącym do porządku idealnego. Idąc dalej należy stwierdzić, że u obu omawianych filozofów podmiot musi być aktywny, musi poddać się presji znaków, jak mówi semiotyk, albo, jak mówi fenomenolog, musi odpowiadać na apel ze strony świata. Następnie trzeba podkreślić, że mimo aktywnej postawy podmiotu to nie on kreuje świat, lecz to świat ujawnia się, pozwala się odkryć. To ujawnianie się świata i świadomość, że odsłonięta prawda o nim należy do wyższego, idealnego porządku może być, jak przypuszczam, źródłem poczucia uczestniczenia w świecie prawdziwym i ważnym. Obaj omawiani tu filozofowie podkreślają, że poznanie może realizować się jedynie w systemach ( u Peirce'a będą to systemy znaków, u Merleau-Ponty'ego będą to systemy rzeczy ) i systemy te cechują się dynamiką. U Peirce'a interpretant spaja świat znaków, jest élan vital tego świata, u MerleauPonty'ego za siłę spajającą świat rzeczy można uznać intencjonalność umysłu ludzkiego, odpowiadanie na apel świata, rzutowanie na świat projektów motorycznych.

Podobieństwo przedstawionych teorii filozoficznych z myślą Rorschacha, w moim odczuciu, należy szukać przede wszystkim w podkreślaniu znaczenia kinestezji.
Zaabsorbowanie szwajcarskiego psychiatry ruchem może odpowiadać aktywnej postawie podmiotu u Merleau-Ponty'ego oraz aktywności samych znaków „domagających się" interpretacji i „porywających” niejako podmiot w ciąg aktów poznawczych. Ważne także jest ujęcie percepcji ruchu jako wyniku identyfikacji z przedmiotem, z wewnętrzną, cielesną reakcją, która towarzyszy spostrzeżeniom wzrokowym. To przełączenie doznań wzrokowych na doznania cielesne można potraktować jako zespolenie z otaczającym środowiskiem, które u Merleau-Ponty'ego Migasiński nazywa komunią ze światem [25]. Zarówno Rorschach, jak i francuski fenomenolog podkreślają rolę ciała w poznaniu. Rorschach nie zdążył rozwinąć swojej teorii percepcji, wyraziście jednak zaakcentował swój pogląd na przeżywanie świata, cechujący się intensywnością i pewną „zachłannością”.

W moim odczuciu, Rorschacha doświadczanie świata można porównać do dynamizmu systemu znakowego $u$ Peirce'a.

16. Myślenie pośrednie i myślenie bezpośrednie uzupełniają się

Buczyńska-Garewicz zauważa, że podczas gdy myślenie bezpośrednie wiąże człowieka ze światem, myślenie poprzez znaki może oddziela go od świata, zwiększać dystans poznającego podmiotu do przedmiotu poznania. Podkresla ona zdecydowane stanowisko Peirce'a, który twierdzi, że jedynie poznanie pośrednie, poprzez znaki jest jedynym wiarygodnym poznaniem; myśl może realizować się tylko w znakach, a więc poznanie bezpośrednie, naoczne nie jest możliwe. Przeżycie naoczności, intuicja, nie przedstawiają sobą żadnej wartości poznawczej. W terminologii ojca fenomenologii, Husserla, poznanie dokonuje się w aktach bezpośredniego uchwycenia znaczenia. Akty te to albo ogląd intelektualny, w którym uchwycenie znaczenia dokonuje się poprzez uchwycenie identyczności znaczenia in abstracto i umożliwia poznanie przedmiotu w całej jego prawdzie, albo akty naznaczone naoczną konkretyzacją ( akty in concreto), które jednak nie należą do istoty poznania, są jedynie jego uzupełnieniem [19]. MerleauPonty percepcję ujmuje już odmiennie. Percepcja u niego zawsze wypełniona jest doświadczeniem świata; zakorzeniona w ciele, nie daje wglądu w pełnię znaczenia, zawsze jest fragmentaryczna i wymaga ponawiania aktów poznawczych. To jednak percepcja jest dla francuskiego fenomenologa istotą poznania, a wszelkie inne jego rodzaje (istnieniu których autor ten nie przeczy) mają swoje źródło i konieczną podstawę w percepcji.

Buczyńska-Garewicz podejmuje dyskusję z definitywnym rozdzielaniem dwóch rodzajów myślenia: pośredniego i bezpośredniego [15]. Dyskusja ta jest ważna dla rozważań podjętych w niniejszym artykule, test Rorschacha był bowiem pomyślany jako test badający 
percepcję, a tutaj postuluje się znakowy charakter plam i odnoszenie się badanych osób do interpretacji plam jako do interpretacji znaków. Buczyńska-Garewicz zwraca uwagę na oczywisty skądinąd fakt, że poznanie przez znaki wymaga percepcji nośnika znaku, a także na omawianą w literaturze dotyczącej percepcji tą jej właściwość, że nie jest ona czymś mechanicznym. „Percepcja materialnego środka przekazu jest już od razu uwikłana w interpretacje znakowe, odczytywana jako droga do poznania czegoś kryjącego się poza środkiem przekazu i odeń odrębnego" [16]. Podobnie odbiór plam atramentowych musi angażować percepcję, ale dla każdego, kto na nie patrzy, oczywistym jest to, że plamy to nie rzeczy, ale ich reprezentacje, znaki. Możemy powiedzieć, że poznanie poprzez znaki może być uzupełnione przez myślenie bezpośrednie, które staje się dla niego tłem. Nie możemy zapominać też o stanowisku teoretyków sztuki, którzy badając percepcję doszli do wniosku, że w swej istocie percepcja to wizualne myślenie [6]. Nie bez znaczenia dla przeprowadzanych tu rozważań jest fakt, że i Rorschach, i Merleau-Ponty percepcję rozumieli bardzo szeroko. Dla Rorschacha była ona złożonym procesem, będącym mieszanką afektu i poznania, angażującym całego człowieka łącznie z jego fizycznością. Peter Galison proponuje rozumienie myśli szwajcarskiego psychiatry w ten sposób, że percepcja tak ma się do interpretacji, jak rodzaj do gatunku, czyli należy przyjąć, że percepcja była dla Rorschacha podstawowym poznaniem, na tle którego dopiero może pojawić się poznanie poprzez znaki. Galison cytuje urywek Psychodiagnostics ( w przekładzie Paula Lemkavu i Bernarda Kronberga): „...the differences between perception and interpretation are dependent on individual factors, not on general ones; that there is no sharp delineation, but a gradual shifting of emphasis; and that interpretation may be called a special kind of perception" [26]. Także dla francuskiego fenomenologa percepcja to istota ludzkiego poznania, możne rzec, ludzkiej egzystencji. Podobnie jak Rorschach traktuje on ją specyficznie, mówiąc: „bezpośredniość odtąd nie jest już impresją, przedmiotem, który stanowi jedno z podmiotem, lecz sensem, strukturą, spontanicznym uporząd kowaniem elementów" [24]. Ponadto, jak pamiętamy, Merleau-Ponty widział niewystarczalność percepcji: jest ona poznaniem bezpośrednim, nie spełnia jednak podstawowego warunku dla myślenia bezpośredniego, jakim jest ujęcie przedmiotu w całej jego prawdzie. To, że Merleau-Ponty był świadomy „pęknięcia” tkwiącego w jego filozofii między przeżywanym doświadczeniem, a myślą sugeruje John Lechte [27]. Buczyńska-Garewicz zwraca uwagę na to, że interpretowanie nie musi być ograniczone do intelektu, że możliwa jest interpretacja emocjonalna i wolincjonalna. Można mieć wrażenie, że i Peirce starał się przezwyciężyć jednostronność swej teorii przez wprowadzenie dodatkowych interpretantów, np. emocjonalnego i energetycznego. Interpretanty te to efekty wywołane przez znak u kogoś, kto ten znak spostrzega i interpretuje. Podążanie tym tropem jednak fałszuje myśl Peirce’a. Amerykański semiotyk zdawał sobie sprawę, że znak nie łączy się wyłącznie z interpretantem logicznym, ale dobitnie podkreśla, że wszystkie interpretacje znaku poza interpretantem logicznym są elementami degenerującymi znak, pozbawiające go pełni jego natury [19] . Nie pozostaje więc nic innego, jak zaakceptować to, że Peirce zainteresowany jest jedynie bytem idealnym, ogólnym i ponadczasowym, że semiotyka jest dla niego po prostu logiką [19]. Stanisław Judycki, omawiając problematykę percepcji zmysłowej, pisze, że natura jej jest tak skomplikowana, że jak dotąd nie dysponujemy satysfakcjonującym wyjaśnieniem tego rodzaju poznania i że diagnoza ta dotyczy i wiedzy przyrodniczej, i filozofii umysłu, i ogólnych rozważań filozoficznych [22]. Myślę, że przyjmując, iż problem poznania ludzkiego należy do podstawowych zagadnień filozoficznych, należy także przyjąć, że podobnie jak i inne kluczowe pytania filozoficzne, są one właściwie nierozstrzygalne, choć jednocześnie nie można z nich rezygnować bez uszczerbku dla myśli ludzkiej i kultury. Myślę, że oba te rodzaje poznania należałoby $\mathrm{w}$ świetle przeprowadzonych rozważań traktować nie tylko jako poznanie w ścisłym tego słowa znaczeniu, ale jako formy doświadczania świata i swego miejsca w tym świecie i że obie te formy uzupełniają się wzajemnie. Możliwe wydaje się także podążenie za myślą Buczyńskiej-Garewicz, która dochodzi do wniosku, że semiotyka wznosi się ponad tradycyjny podział zdolności umysłu i zaciera granice między jego władzami [16]. Interpretację, jako istotny element znaku, można traktować jako zjawisko wielowymiarowe, a ta wielość, różnorodność dotyczyłaby zarówno znaczenia znaku, jak i jego nośnika. Należałoby wówczas przyjąć, że interpretacja, jako kategoria nadrzędna, jest istotnym sposobem przeżywania świata i istotną formą kontaktu ze światem; możemy więc do licznych określeń człowieka dodać następne, a mianowicie: „człowiek interpretujący”.

\section{Wnioski}

W końcu należałoby zastanowić się, jakie znaczenie dla psychologa praktyka mają przeprowadzone wyżej rozważania. Myślę, ze nigdy nie jest zbędne głębsze rozumienie natury narzędzia, jakim posługujemy się $\mathrm{w}$ badaniu. Zaangażowanie osoby badanej, zaangażowanie badającego może wynikać nie tylko z ich osobistych postaw, ale także ze specyfiki stosowanych bodźców. Psycholog powinien być świadomy, że sytuacja badania testem Rorschacha może intensyfikować sposób, w jaki osoba badana zwraca się ku światu, może ukazywać jej dwa podstawowe doświadczenia w ujmowaniu 
świata: doświadczenie związane $\mathrm{z}$ percepcją świata $\mathrm{i}$ doświadczenie związane $\mathrm{z}$ interpretacją świata. Jak starałam się wykazać, te dwa sposoby doświadczania świata nie są alternatywne, lecz wzajemnie się przenikają. Jeśli przyjmiemy, że interpretacja jest nie tylko epistemologiczną, lecz także ontologiczną kategorią, to należy również przyjąć, że nasze działania interpretacyjne są realizacją ontycznej, międzyznakowej interpretacji. Sytuacja badania testem Rorschacha nabiera wówczas wymiaru egzystencjalnego, ukazuje istotę naszego uczestnictwa w świecie, a pozycja osoby badanej i badającej staje się jednopoziomowa, partnerska.

\section{Conflict of interest}

The author has declared no conflict of interest.

\section{References:}

1. Exner JE. The Rorschach Comprehensive System. Hoboken, NJ; John Wiley and Sons: 2003.

2. Akavia N. Subjectivity in motion: Life, art, and movement in the work of Hermann Rorschach. New York, NY; Routledge: 2013.

3. Paluchowski WJ. Teoretyczna analiza i diagnostyczne znaczenie metody H. Rorschacha. In: Paluchowski WJ, ed., Z zagadnień diagnostyki osobowości. Warsaw, Kraków, Gdańsk, Łódź; Wydawnictwo PAN: 161-182. Polish.

4. Stasiakiewicz M. Podmiotowe i sytuacyjne wyznaczniki badania testem Rorschacha. Poznań; Wydawnictwo Naukowe UAM: 1994. Polish.

5. Searls D. The Inkblots. Hermann Rorschach, his iconic test, and the power of seeing. New York, NY; Crown Publishing Group: 2017.

6. Arnheim R. Visual thinking. Berkeley, Los Angeles, London; University of California Press: 1969.

7. Hunca-Bednarska A. Nieco inaczej o teście plam atramentowych Hermanna Rorschacha. Eseje. Lublin; Wydawnictwo KUL: 2013 Polish.

8. Leśniak FL. Perceptanaliza w perspektywie pozytywnej dezintegracji. Metoda Rorschacha dla zaawansowanych. Warsaw; PTHP: 1994. Polish.

9. Arnheim R. Sztuka i percepcja wzrokowa. Psychologia twórczego oka. Trans. Jolanta Mach. Warsaw; Wydawnictwo Artystyczne i Filmowe: 1978. Polish.

10. Mitchell T. Piśmienność wizualna czy wizualność piśmienna? Teksty Drugie, 2012; 133-134(1/2): 153-163. Polish.

11. Deręgowski JB. Oko i obraz. Studium psychologiczne. Trans. Krystyna Dudziak. Warsaw; PWN: 1990. Polish.

12. Rapaport D, Gill MM, Schafer R. Diagnostic psychological testing. New York, NY; International Universities Press: 1975.

13. Paluchowski WJ. Diagnoza psychologiczna. Podejście jakościowe i ilościowe. Seria Wykłady z psychologii, t. 7. Warsaw; Wydawnictwo Naukowe „Scholar”: 2001. Polish.

14. Durand G. Wyobraźnia symboliczna. Trans. Cezary Rowiński. Warsaw; PWN: 1986. Polish.

15. Hunca-Bednarska A. Koncepcja ruchu w teście Hermanna Rorschacha. Refleksje nad książką Naamah Akavii: Subjectivity in Motion. Life, Art, and Movement in the Work of Hermann Rorschach. Curr Probl Psychiatry, 2015; 16(2): 113-123. Polish.

16. Buczyńska-Garewicz H. Słowo wstępne: Semiotyka i filozofia Znaku. In: Bense M. Świat przez pryzmat znaku. Trans. Jan Garewicz. Warsaw; PIW: 1980: 5-42. Polish.
17. Hunca-Bednarska A. Skojarzenia werbalne w schizofrenii. Lublin; Wydawnictwo Czelej: 1997. Polish.

18. Guiraud D. Semantyka. Trans. Stanisław Cichowicz. Warsaw; Wiedza Powszechna: 1976. Polish.

19. Buczyńska-Garewicz H. Rozum szukający i błądzący. Eseje o filozofii i filozofach. Toruń; Wydawnictwo Adam Marszałek: 2007. Polish.

20. Buczyńska-Garewicz H. Znak, znaczenie, wartość. Szkice o filozofii amerykańskiej. Warsaw; Książka i Wiedza: 1975. Polish.

21. Kalaga W. Mgławice dyskursu. Kraków; Universitas: 2001. Polish.

22. Judycki St. Percepcja zmysłowa. https://www.kul.pl/materiałydo pobrania, 23.08.2021. Polish.

23. Malmgren H. Rorschach's idea of a "movement" response in the light of recent philosophy and psychology of perception. Rorschachiana, 2000; 24(24): 1-

24. Merleau-Ponty M. Fenomenologia percepcji. Trans. Małgorzata Kowalska i Jacek Migasiński. Warszawa; Fundacja Aletheia: 2001.

25. Migasiński J. Fenomenologia Merleau-Ponty’ego. In: MerleauPonty. Fenomenologia percepcji. Trans. Małgorzata Kowalska \& Jacek Migasiński. Warsaw; Fundacja Aletheia: 2001: 479-486. Polish.

26. Galison P. Image of self. In: Daston I, ed., Things that talk: Object lessons from art and science. New York, NY; Zone Books: 2008: 257-294.

27. Lechte J. Panorama współczesnej myśli humanistycznej. Od strukturalizmu do postmodernizmu. Trans. Tadeusz Baszniak. Warsaw; Książka i Wiedza: 1999. Polish.

\section{Corresponding author}

Anna Hunca Bednarska

Stowarzyszenie MONAR

Poradnia Profilaktyki, Leczenia

i Terapii Uzależnień w Lublinie

20-214 Lublin, ul. Montażowa 15

Otrzymano: 26.08.2021

Zrecenzowano: 30.11.2021

Przyjęto do druku: 14.01.2022 